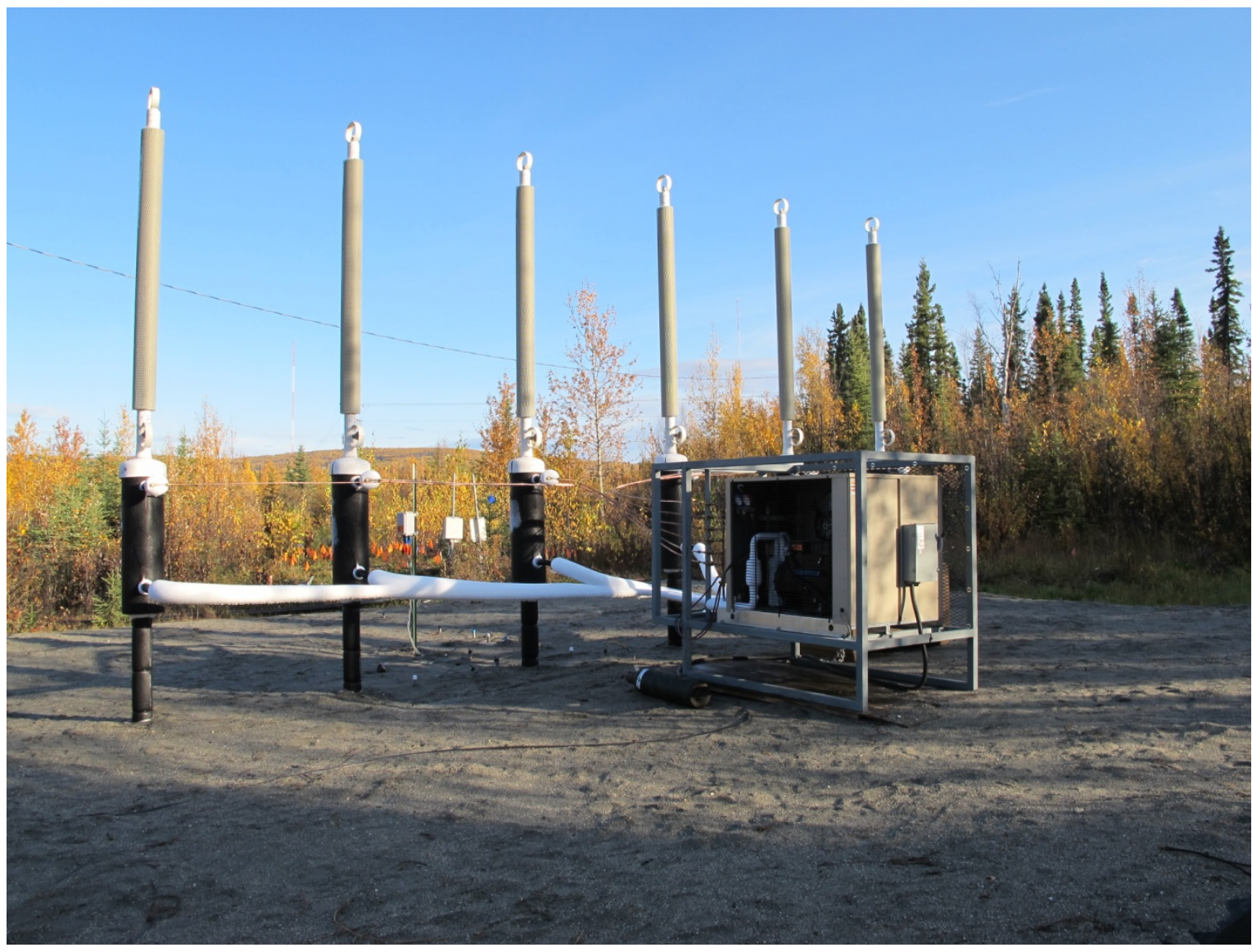




\section{Demonstration of an Artificial Frozen Barrier}

Anna M. Wagner

Cold Regions Research and Engineering Laboratory

U.S. Army Engineer Research and Development Center

72 Lyme Road

Hanover, NH 03755

Edward Yarmak, Jr.

Arctic Foundations Inc.

5621 Arctic Boulevard

Anchorage, AK 99518-1667

Approved for public release; distribution is unlimited.

Prepared for U.S. Army Corps of Engineers

Washington, DC 20314-1000 


\section{Abstract}

Groundwater is the main source of drinking water for the majority of the U.S. population. Unfortunately, groundwater is susceptible to contamination from major sources, such as storage tanks, hazardous waste sites, landfills, and septic systems. Polluted groundwater can endanger public health or threaten the environment. Standard containment technologies include slurry walls, reactive barriers, sheet piling, and grouting. Another less common technique is freezing the contaminants in situ. The objective of this study is to create a frozen soil barrier using thermosyphons. The first phase of this study is presented in this report and investigated how long it takes for the rate of bulk soil freezing to complete the frozen soil barrier. At this installation, freezing to closure occurred after about 42 days and the barrier was $1 \mathrm{~m}$ thick after approximately 48 days. The average electricity usage was $132 \mathrm{kWh} /$ day.

DISCLAIMER: The contents of this report are not to be used for advertising, publication, or promotional purposes. Citation of trade names does not constitute an official endorsement or approval of the use of such commercial products. All product names and trademarks cited are the property of their respective owners. The findings of this report are not to be construed as an official Department of the Army position unless so designated by other authorized documents. 


\section{Table of Contents}

Abstract......................................................................................................................................... ii

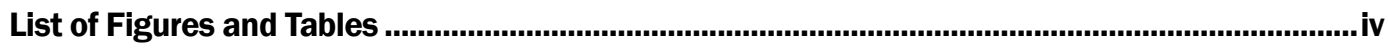

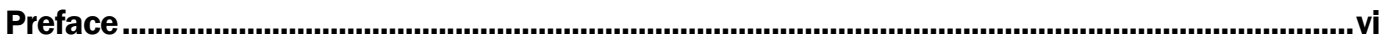

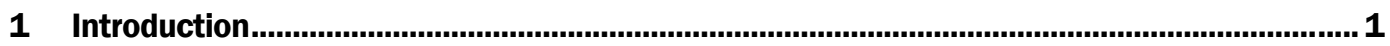

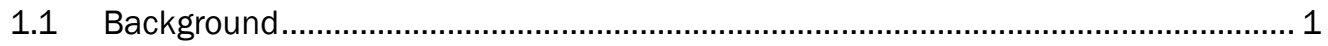

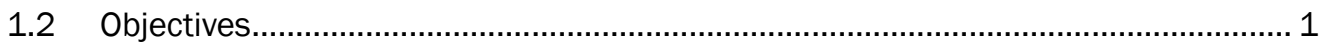

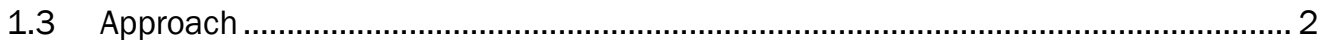

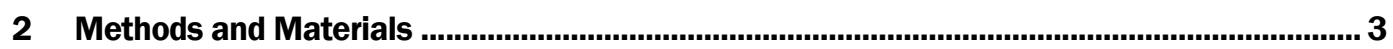

2.1 Artificial freezing technology .................................................................... 3

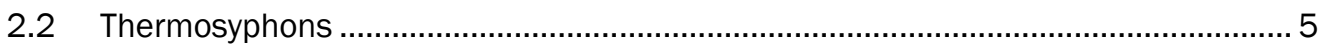

2.3 Site selection: resistivity measurements ........................................................ 6

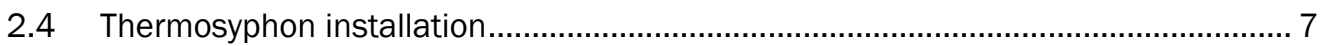

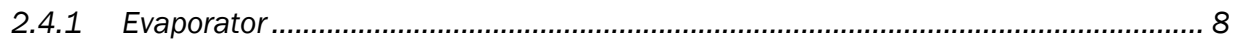

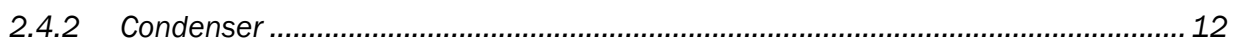

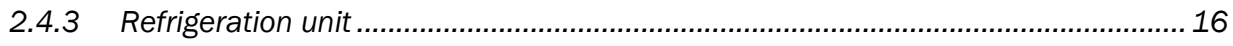

2.4.4 Insulation and impermeable cover .............................................................. 17

2.5 Ground temperature monitoring ...................................................................... 18

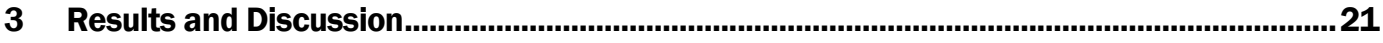

3.1 Ground temperature measurements.............................................................. 21

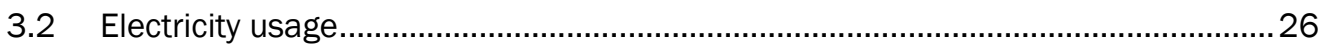

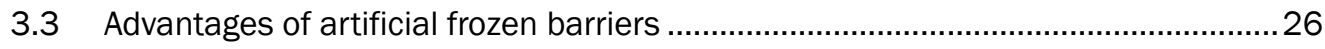

References.............................................................................................................................28

\section{Report Documentation Page}




\section{List of Figures and Tables}

\section{Figures}

Figure 1. Different types of frozen barrier configurations such as a frozen wall, an enclosure, and a frozen block of soil. ...................................................................................... 4

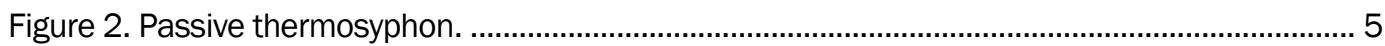

Figure 3. 2D resistivity line at the potential site of installation ......................................................... 6

Figure 4. Prior to installation of barrier, with blue flags indicating the locations of the

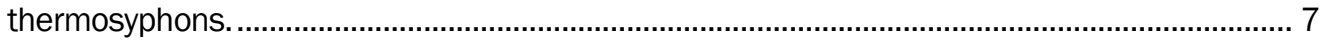

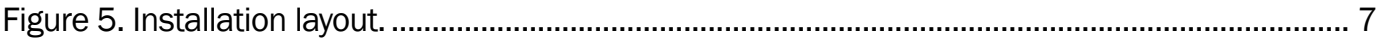

Figure 6. Installation of third evaporator................................................................................. 8

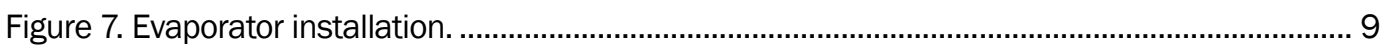

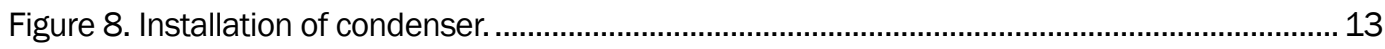

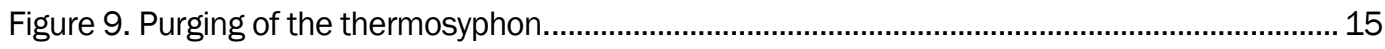

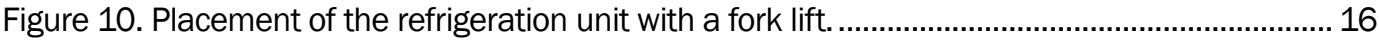

Figure 11. Installation of insulation.............................................................................................. 17

Figure 12. Impermeable cover. ......................................................................................... 17

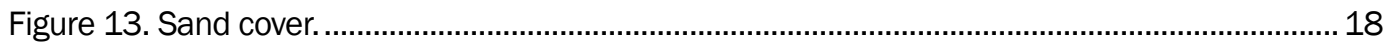

Figure 14. Placement of PVC pipes for ground temperature monitoring....................................... 18

Figure 15. Sand backfill of ground temperature PVC pipe, and evaporator and

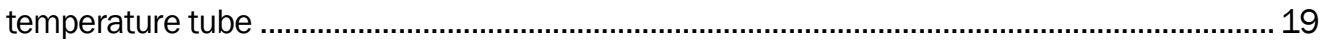

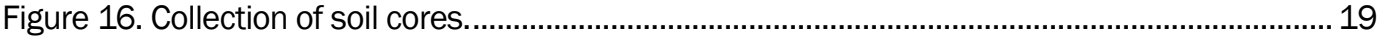

Figure 17. Layout of ground temperature monitoring locations.........................................................2 20

Figure 18. Ground temperatures for several locations (ITTP1, ITTP2, ITTP3, ITTP4, ITTP5, ITTP6, ITTP7, ITTP8, ITTP9, ITTP10, and ITTP50) at ground depths of surface (top, interface between ground surface and insulation), 0.6, 1.2, and $1.8 \mathrm{~m}$................................. 22

Figure 19. Ground temperatures for several locations (ITTP1, ITTP2, ITTP3, ITTP4, ITTP, ITP6, ITTP7, ITP8, ITTP9, ITP10, and ITP50) at ground depths of 2.4, 3.0, 4.6, and $6.1 \mathrm{~m}$ 
Figure 20 Ground temperatures for several locations (ITTP1, ITTP2, ITTP3, ITTP4, ITTP5, ITTP6, ITTP7, ITTP8, ITTP9, ITTP10, and ITTP50) at ground depths of surface, 7.6, 9.1, and $10.7 \mathrm{~m}$ 24

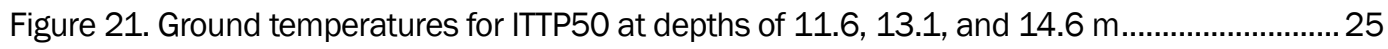

Figure 22. Electricity usage and average air temperatures during the active phase........................26

\section{Tables}

Table 1. Active system start and end temperatures for ITTP10 (control) and ITTP50

(middle of barrier) at different ground depths $(0,0.6,1.2,1.8$, and $2.4 \mathrm{~m})$. 


\section{Preface}

This study was conducted at Fort Wainwright, AK, for the U.S. Army Assistant Chief of Staff for Installation Management (ACSIM) under Installation Technology Transfer Program (ITTP) Project FY11-25, Frozen Soils as Barriers to Isolate Contaminants. The technical reviewer for ACSIM was Malcolm Garg, DAIM-ISE; and the ITTP Program Manager was Debbie J . Lawrence, CEERD-CV-T.

The work was performed by Anna M. Wagner (Biogeochemical Sciences Branch, Dr. Terry Sobecki, Chief), U.S. Army Engineer Research and Development Center- Cold Regions and Engineering Laboratory (ERDCCRREL), and Edward Yarmak, J r., Arctic Foundations Inc., Anchorage, AK. At the time of publication, Dr. J ustin Berman was Chief, Research and Engineering Division; and Kevin Knuuti was Technical Director for Earth Sciences and Engineering. The Deputy Director of ERDC-CRREL was Dr. Lance Hansen. and the Director was Dr. Robert E. Davis.

COL Kevin J . Wilson was the Commander and Executive Director of ERDC, and Dr. J effery P. Holland was the Director. 


\section{Introduction}

\subsection{Background}

By 2005, Department of Defense (DoD) had identified 6000 sites that require groundwater remediation (USGAO 2005). Groundwater accounts for about $50 \%$ of the Nation's municipal, domestic, and agricultural water supply (USGS 1993). When groundwater becomes polluted, it can endanger public health or threaten the environment. Typically, contaminated sites consist of a source zone where the bulk of the contaminant is concentrated and a surrounding plume of contamination that develops as a result of groundwater flowing through the contaminated site. Containment of the source area can prevent the release of contaminants. The groundwater contaminant plume can also be controlled by altering the natural groundwater gradient with extraction wells, or other sinks, such that the contaminant plume is directed towards these locations where the contaminated groundwater can be treated.

Standard containment technologies include slurry walls, reactive barriers, sheet piling, grouting, or their combination. These are permanent structures that, once installed, are difficult and expensive to remove. Another technique, not as widely used, is the creation of frozen barriers using artificial freezing techniques. Artificial freezing can be used in any climate and has primarily been used for deep excavation, tunneling, and underground construction (Hass and Schäfers 2006). Frozen barriers can be created using artificial freezing to temporarily contain contamination during remediation activities or can be installed for long-term use where other remediation techniques have been shown to be unsuccessful or not economic feasible (Lynn et al. 2000). In most cases, a frozen barrier may be removed by simply deactivating the freezing system once containment is no longer required (Long and Yarmak 2000).

\subsection{Objectives}

The objective of this study was to test and evaluate a commercially available technology (hybrid thermosyphons) to freeze the ground and create a frozen barrier to prevent contaminant migration to groundwater. This report includes documenting the time required for the barrier to freeze to 
closure, the installation procedure of the system, and the electricity usage associated with running the active system.

\subsection{Approach}

This report provides the technical details of the installation of a full-scale frozen barrier at Ft. Wainwright, AK, using actively cooled hybrid thermosyphons. The hybrid system is a combination of active and passive thermosyphons, where the passive system operates when temperatures are below freezing and the active system (that includes a refrigeration unit) when the temperatures are above freezing. The system was installed in $\mathrm{J} \mathrm{u}$ ly of 2011 and the time to freeze was monitored using temperature sensors installed throughout the site. Data provided in this report include soil temperatures from 62 days of freezing using the actively cooled thermosyphon system and from 19 days of thawing once the system was turned off. The installation will continued to be monitored to evaluate how well the passive performance of the thermosyphons maintains the barrier.

The report has three sections. Section 1 is the introduction, Section 2 provides a summary about thermosyphons and the installation of the barrier, and Section 3 presents results and discussion. 


\section{Methods and Materials}

\subsection{Artificial freezing technology}

Artificial freezing can be used to create a frozen barrier that restricts migration of aqueous phase contaminants. Therefore, a barrier can contain subsurface contamination resulting from accidental spills or from accidental releases from facilities such as underground storage tanks. Freezing of the source area can prevent the release of contaminants or the barrier can be used to direct the contaminant plume toward extraction wells or other remedial technologies. The frozen barrier can also serve as a temporary structural retaining wall if subsequent excavation of contaminated soils is needed, provided there is additional engineering (other than that for freezing) to determine the safety of the walls. They can be used alone or in concert with additional remedial technologies at contaminated sites to control risk and prevent the off-site migration of contaminants. They are applicable in all soil and rock types where sufficient water is available to fill the pores and voids with ice when frozen. To create frozen barriers in very low water content soils, water can be introduced (Andersland et al. 1996). Frozen barriers may be constructed in both the saturated and vadose zones. Freezing temperatures draw water vapor toward the barrier and that vapor will condense and help to fill voids.

Even though some pore water remains unfrozen when the soil temperature is below freezing, the hydraulic conductivity in ice rich soils has been measured to $1 \times 10^{-9} \mathrm{~cm} / \mathrm{s}$ (extremely low) at a temperature of $-4^{\circ} \mathrm{C}$ (McCauley et al. 2002). Note that, in Alaska, the hydraulic conductivity of secondary containment for fuel spills must be less than $1 \times 10^{-6} \mathrm{~cm} / \mathrm{s}$ (ADEC 1996), which is a triple order of magnitude greater than $1 \times 10^{-9}$ $\mathrm{cm} / \mathrm{s}$. To assure a low hydraulic conductivity for the frozen barrier, it should be designed to have a core temperature that is well below freezing.

Frozen barriers are formed using a series of subsurface freezing pipes or probes (Fig. 1). The adjacent soil forms a frozen column the length of the freezing pipe and the diameter of the frozen soil column increases with time, at a rate depending upon the specific soil, moisture, and thermal conditions at a given site and refrigeration rate, i.e., pipe temperature. The barrier is completed once the diameters of the frozen soil columns merge, which is called "freezing to closure." The design thickness of the frozen 
wall can be controlled by either adjusting the size or temperature of the pipes or by installing additional rows of freezing pipes. The barrier can be designed in many different configurations including:

- A vertical wall.

- An enclosure.

- A solid block of frozen soil.

- An impervious barrier shaped underneath the source.

a)

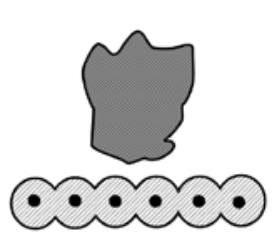

b)

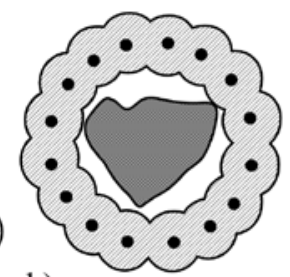

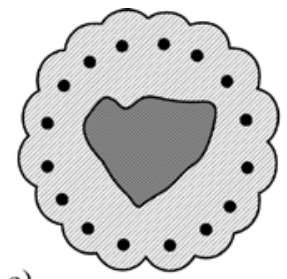

c)

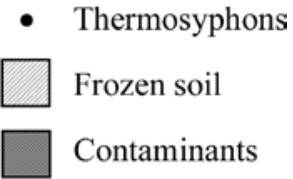

Contaminants

Figure 1. Different types of frozen barrier configurations such as a) a frozen wall, b) an enclosure, and c) a frozen block of soil.

Freezing soil for groundwater control is a technique that has been used by the construction and mining industries for almost 150 years since its inception by Poetsch in 1863 (Sullivan et al. 1984). Conventional ground freezing uses chilled brine (usually a mixture of calcium chloride and water) circulated through freezing pipes inserted into the ground to create a frozen wall. The technology of conventional ground freezing has remained essentially the same since its debut, with modernization of the piping, pumping, control, and refrigeration systems. At a remediation site, the "antifreeze" brine is a potential additional contaminant to deal with if lost through a pipe rupture or other form of spill (ASHRAE 1998). Over the short term, a small brine spill may be innocuous, but if the frozen barrier is a long-term solution, a brine spill may compromise the integrity of the barrier. Another technique for creating frozen walls for groundwater control for construction uses liquid nitrogen $\left(\mathrm{LN}_{2}\right)$ to cool the freezing pipes or probes. The $\mathrm{LN}_{2}$ evaporates from the pipes at $-195^{\circ} \mathrm{C}$ and rapidly chills the surrounding materials. $\mathrm{LN}_{2}$ is often used where groundwater velocities are too high for conventional ground freezing systems to handle or when very rapid, short-term freezing is desired. Once groundwater is controlled, other freezing techniques may be employed for long-term maintenance of the frozen wall. 


\subsection{Thermosyphons}

Thermosyphons are passive, pressurized, sealed pipes charged with a working fluid (see Fig. 2) that goes through convection when there is a temperature difference between the evaporator and condenser, leading to a one-way transport of ground heat. They have been used for foundation stabilization in continuous and discontinuous permafrost areas since 1960 (Long 1963). More recently, thermosyphons have been used successfully to prevent contaminant migration from tailings dams in Canada and Russia (French 2007). They operate by vaporization of the working fluid at the lower buried end while the working fluid condenses at the upper exposed end. Currently, carbon dioxide $\left(\mathrm{CO}_{2}\right)$ is the most commonly used working fluid in North American applications.

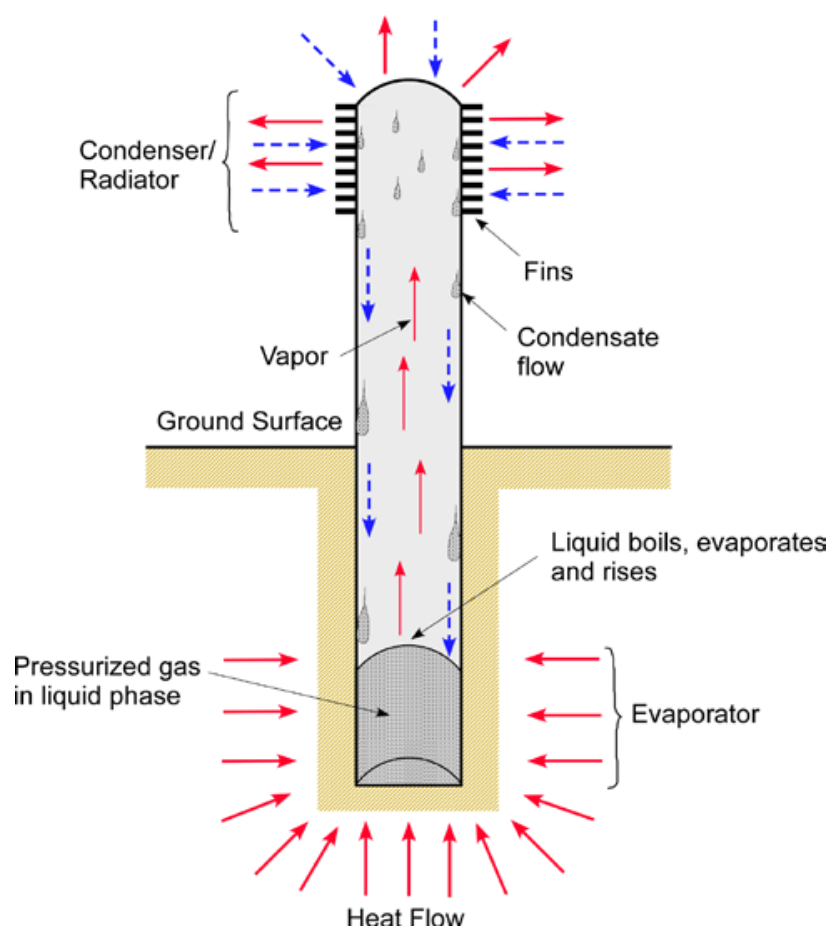

Figure 2. Passive thermosyphon.

There are three types of thermosyphons: 1) passive; 2) active; and 3) hybrid.

Passive thermosyphons function without external power and operate only when the temperature of the top (exposed) end is below the temperature of the lower (embedded) portion. For freezing to occur, they require air temperatures that are below freezing and lower than ground temperatures. Active thermosyphons are linked to a heat pump and can be used in any 
climate or when an immediate freeze-up is needed. The passive and the active techniques can be combined into a hybrid system. The hybrid system functions passively when ambient temperatures are sufficiently low, thereby reducing energy costs. Once ambient temperatures rise above freezing, the active system can be started.

Typically, passive thermosyphons are used in continuous and discontinuous permafrost zones and active thermosyphons are used in more temperate climates. Hybrid thermosyphon deployment is determined by the constraints and requirements of the individual project.

\subsection{Site selection: resistivity measurements}

To determine the location and size of the thermosyphon system, a soil survey of the potential site was needed. The potential site was a disturbed location where soils consist of tan silt and windblown loess near the surface and grey silt at depths below $1.4 \mathrm{~m}$. Surface geophysical methods can be used to accurately and rapidly map permafrost extent over limited areas and to determine changes in permafrost extent and thickness over time. Electrical resistivity tomography is one method that is commonly used to measure and map the electrical resistivity of the soil to infer areas of permafrost. Those areas that exhibit high resistivity indicate zones that are likely to be frozen (permafrost) or to vary from the surrounding ground in some way (potential buried debris, impervious strata, etc.). One 2-D line was collected with an AGI Supersting R8/IP multi-channel switch resistivity meter and passive cables prior to installing the frozen barrier system. An example of the results obtained from this line is shown in Figure 3. An electrode spacing of $1 \mathrm{~m}$ resulted in a total length of $84 \mathrm{~m}$. The potential site for the installation was at about $46 \mathrm{~m}$. We estimated from the resistivity measurements that the permafrost was located at about $9 \mathrm{~m}$ deep. Permafrost moisture contents range from 26 to $41 \%$ by mass for the frozen silts, which shows that this permafrost has relatively low moisture content.

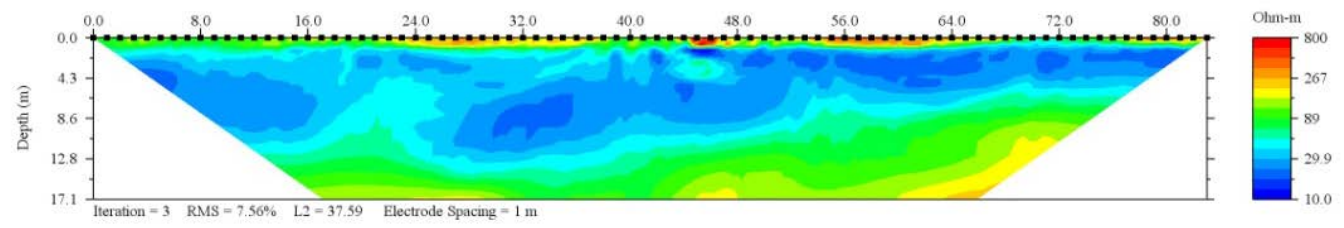

Figure 3. 2-D resistivity line at the potential site of installation (note that the measurements are in meters). 


\subsection{Thermosyphon installation}

The actual site chosen for the thermosyphon aligned with the site where the resistivity measurements took place. Figure 4 shows the site prior to installation, with blue flags indicating the proposed location of the thermosyphons. The layout of the installation is illustrated in Figure 5. The frozen barrier test section consisted of six thermosyphons.

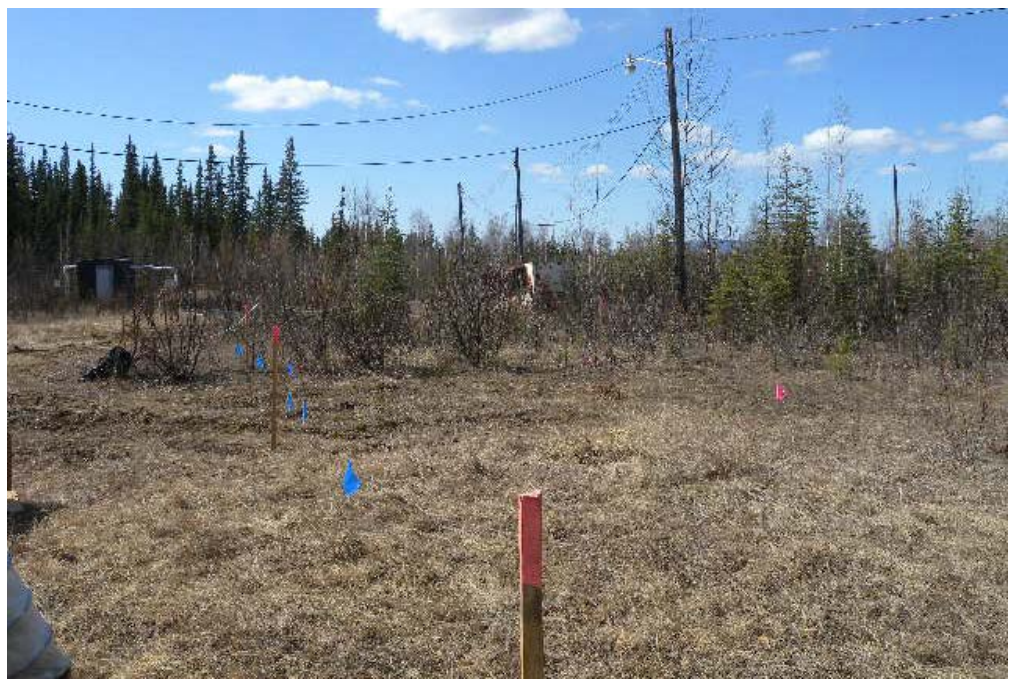

Figure 4. Prior to installation of barrier, with blue flags indicating the locations of the thermosyphons.

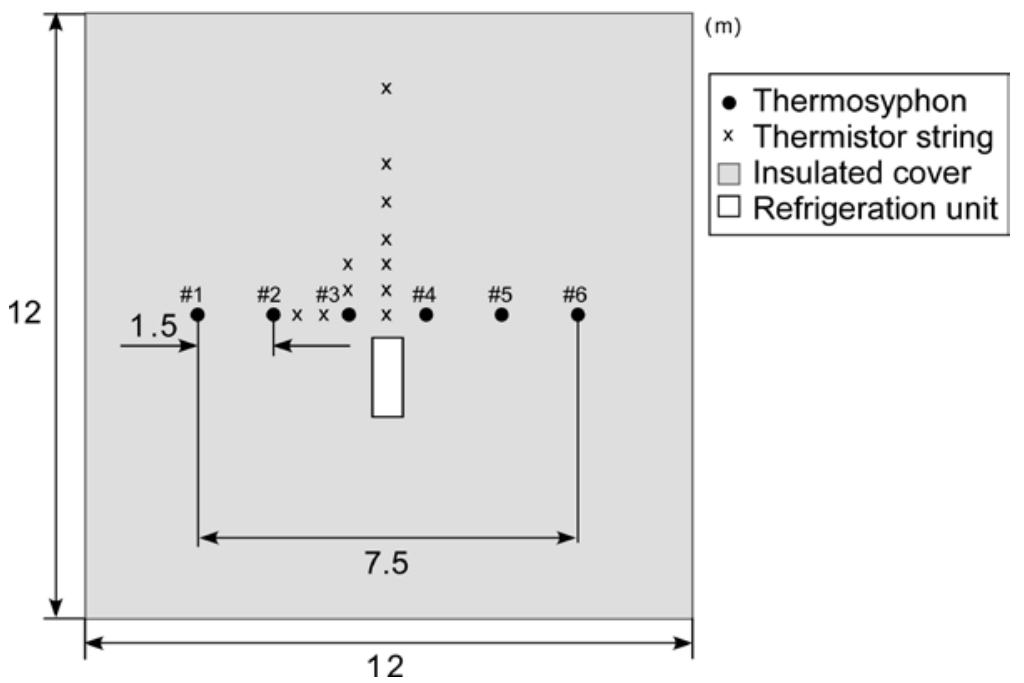

Figure 5. Installation layout. 


\subsubsection{Evaporator}

The pressure tested evaporators were built to a length of $12.2 \mathrm{~m}$ to assure that they would extend into the permafrost. The soils at the site are very wet and caving at certain depths made it impossible to place the evaporators directly into a drilled hole. We decided to use a non-standard nominal diameter of $63.5 \mathrm{~mm}$ for the evaporators to fit them inside an $82.6 \mathrm{~mm}$ inner diameter triple key hollow stem auger. A Geoprobe 7822 track mounted direct push drill rig was used to drill holes for the evaporator and thermistor strings (Fig. 6). The evaporators were placed using a 3636-kg variable forklift (Fig. 7). After the evaporator was dropped into the hollow stem auger, the auger was removed, and the evaporator was plumbed, while sand was used to backfill the void surrounding the evaporator (Fig. 7).

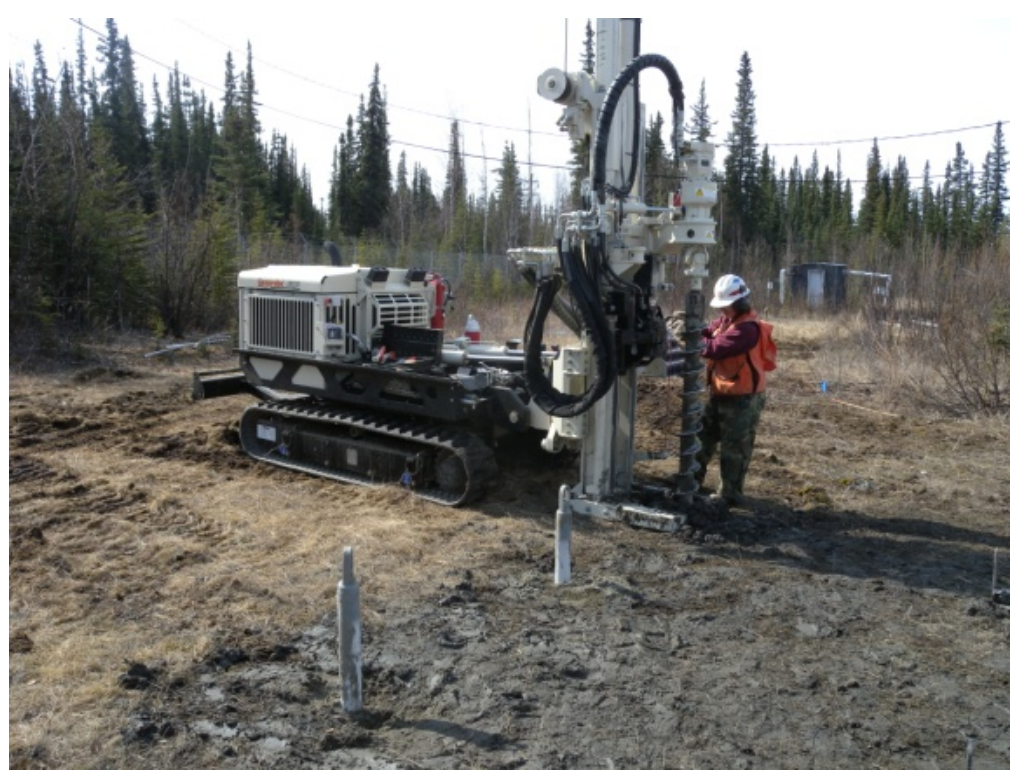

Figure 6. Installation of third evaporator. 


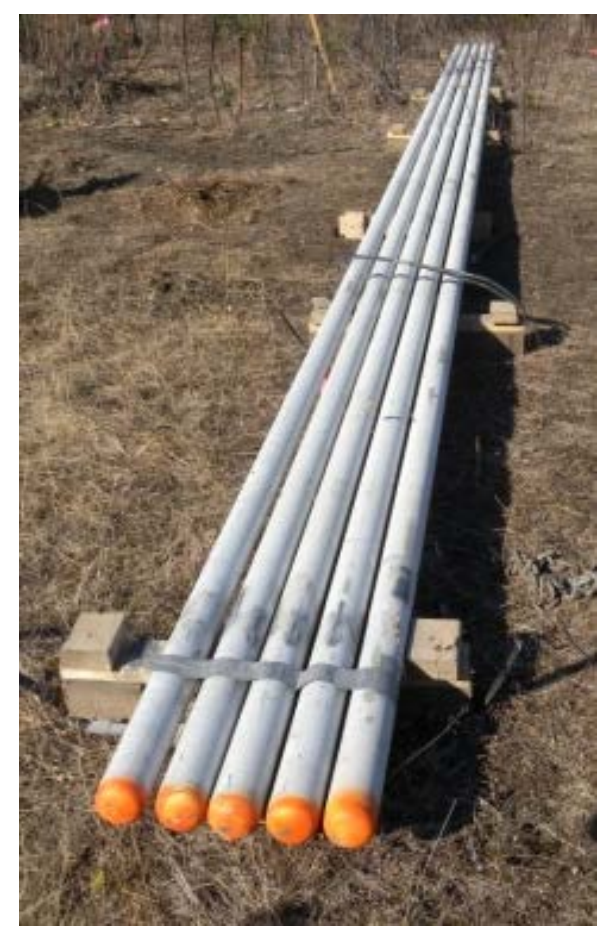

a. Evaporators before placement in ground.

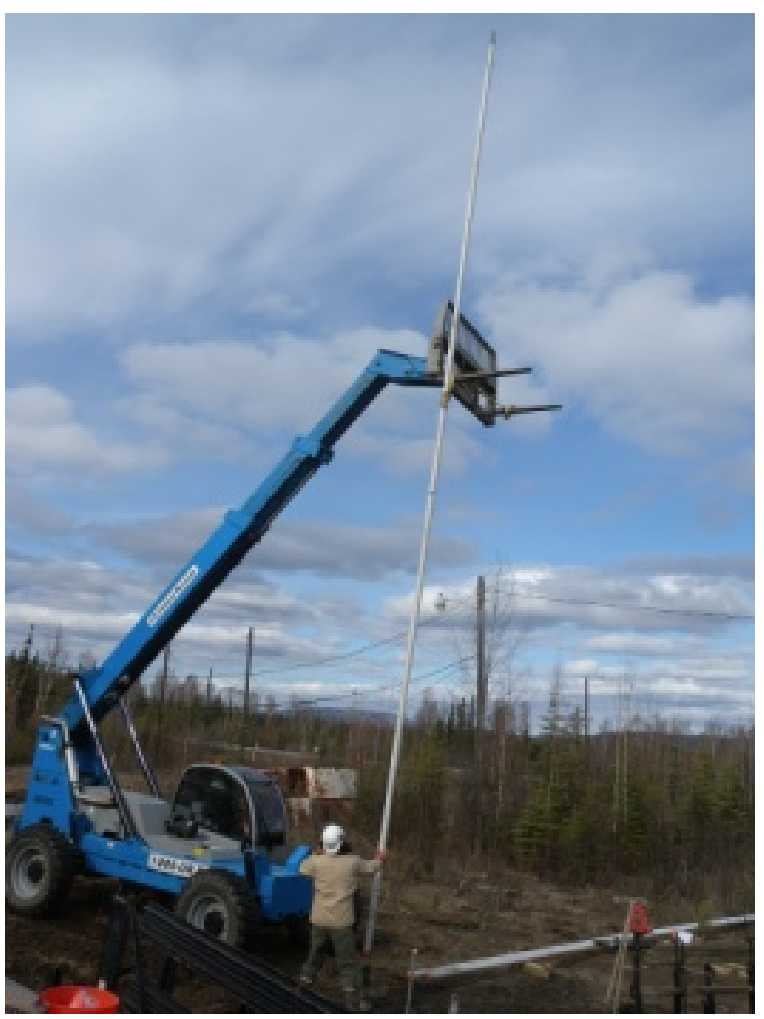

b. Placement of evaporator using a fork lift.

Figure 7. Evaporator installation. 


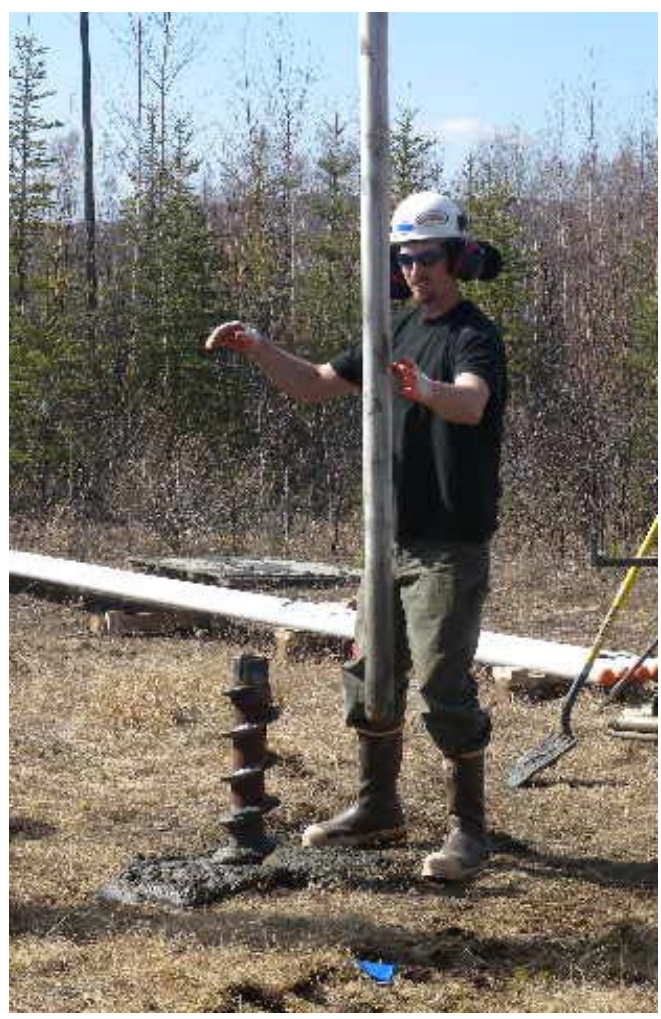

c. Directing evaporator to be placed.

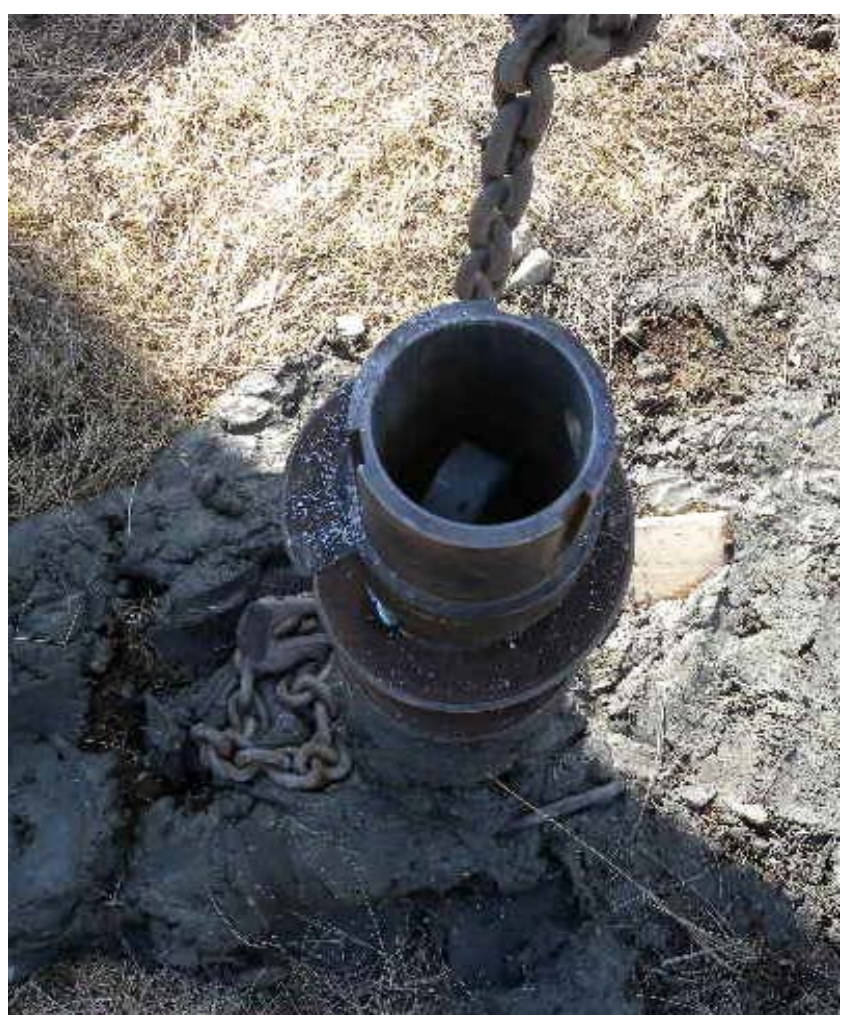

d. Inside hollow stem auger.

Figure 7 (cont'd). Evaporator installation. 


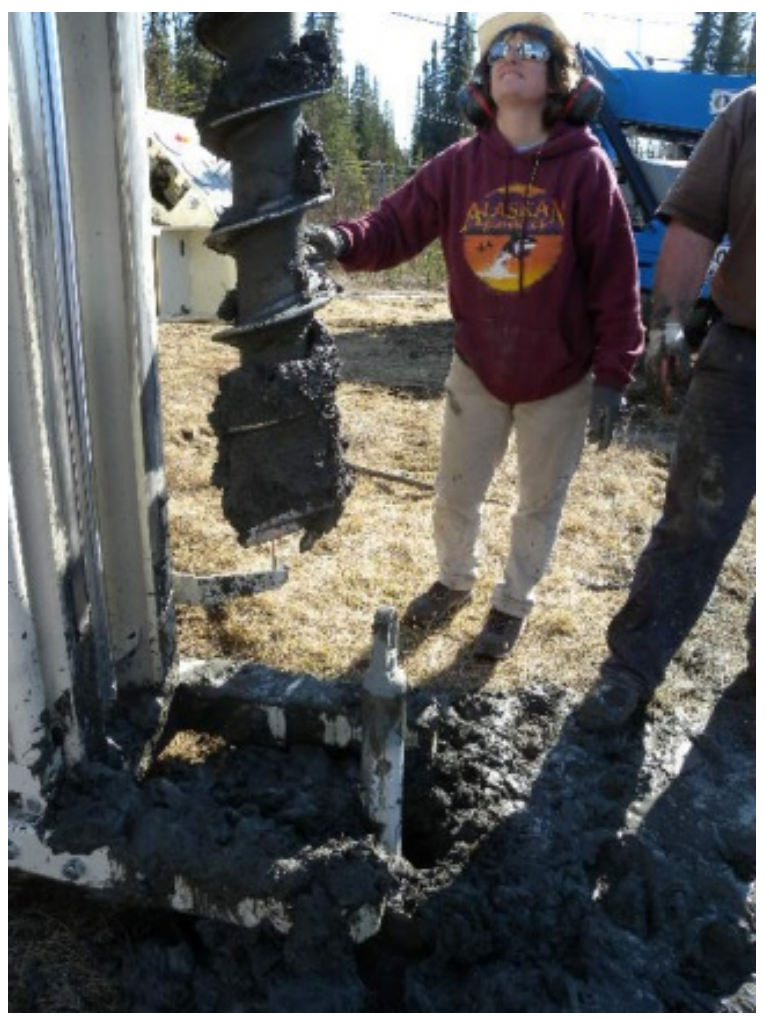

e. Removing hollow stem auger.

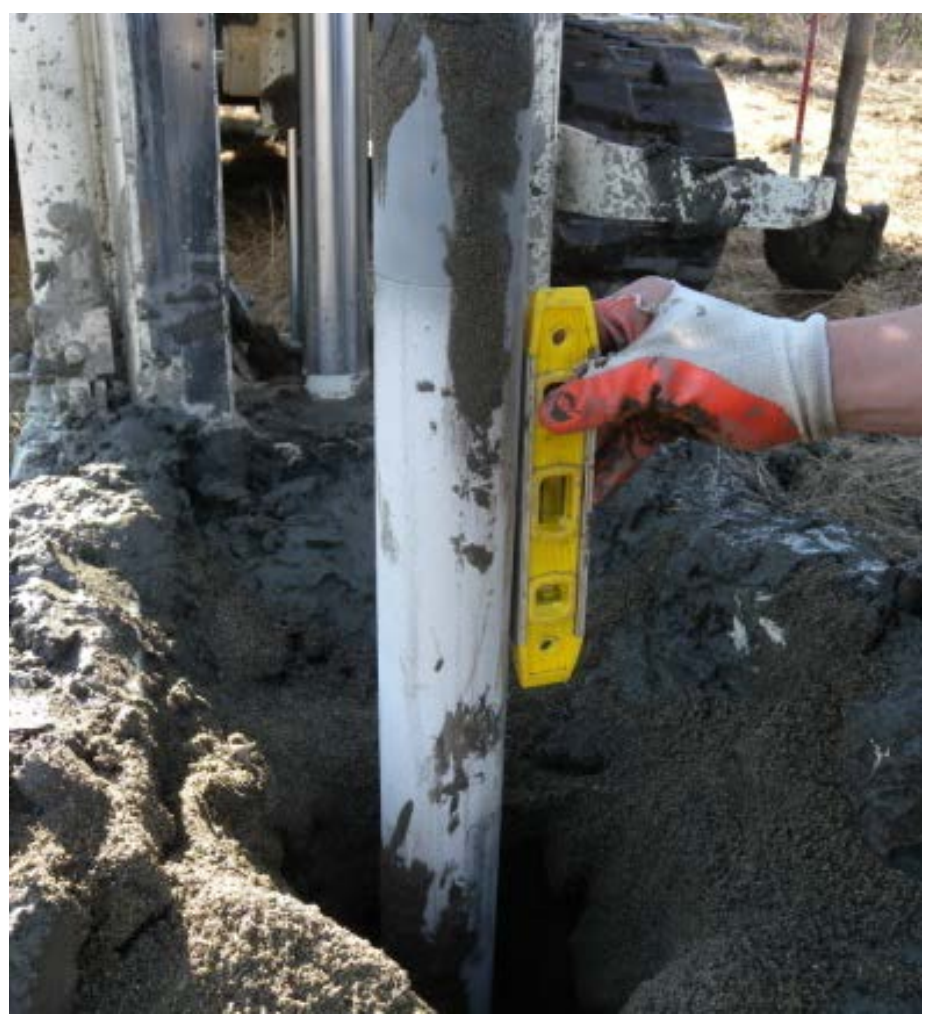

f. Leveling of evaporator.

Figure 7 (cont'd). Evaporator installation. 


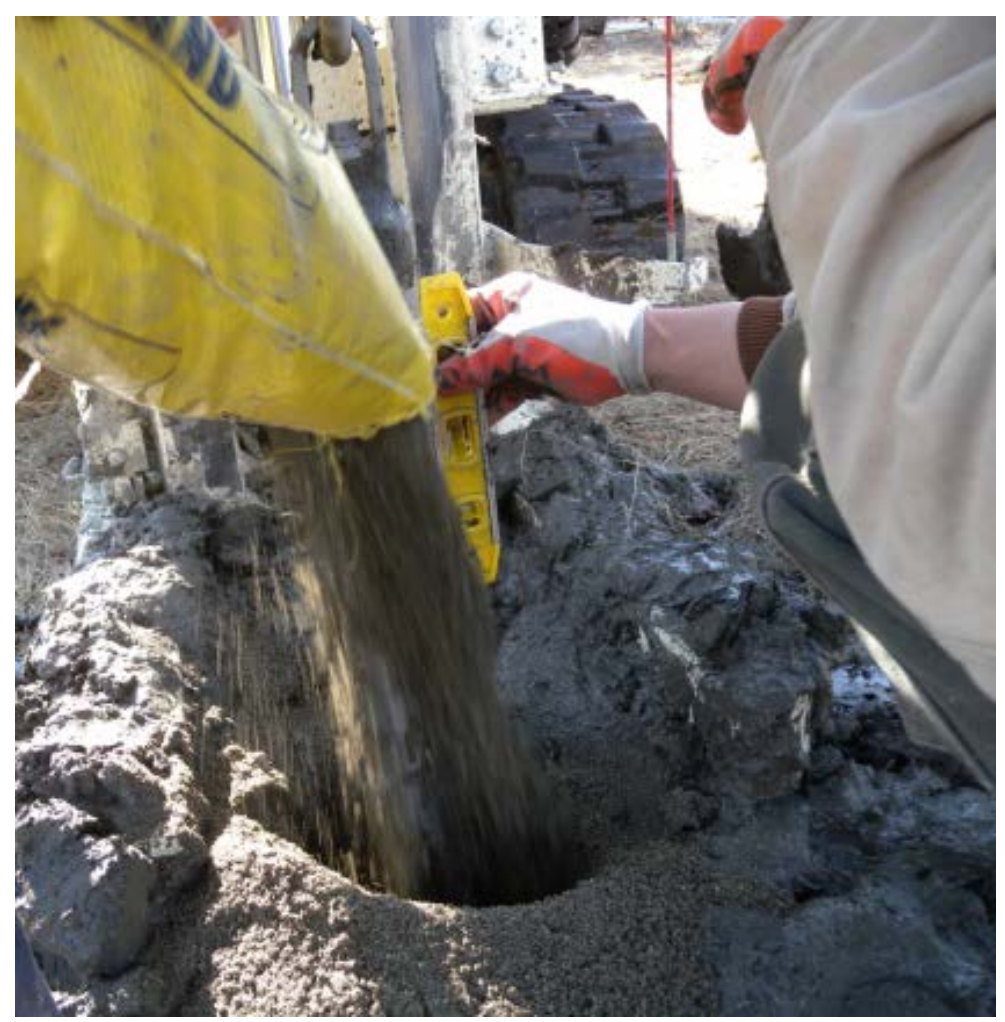

g. Backfilling with sand around evaporator.

Figure 7 (cont'd). Evaporator installation.

\subsubsection{Condenser}

The thermosyphon condenser was installed in the field after the evaporator owing to constraints of the overall project. The temporary lifting loop on top of the evaporator was cut off prior to installing the condenser (Fig. 8). The condenser was placed on top of the evaporator using a 2727-kg variable forklift. A 300-A arc welder was used to join the evaporator and condenser. The total area of the condenser fins was $6.5 \mathrm{~m}^{2}$. Then, the thermosyphon was purged, filled, and pressurized with $\mathrm{CO}_{2}$ (Fig. 9). 


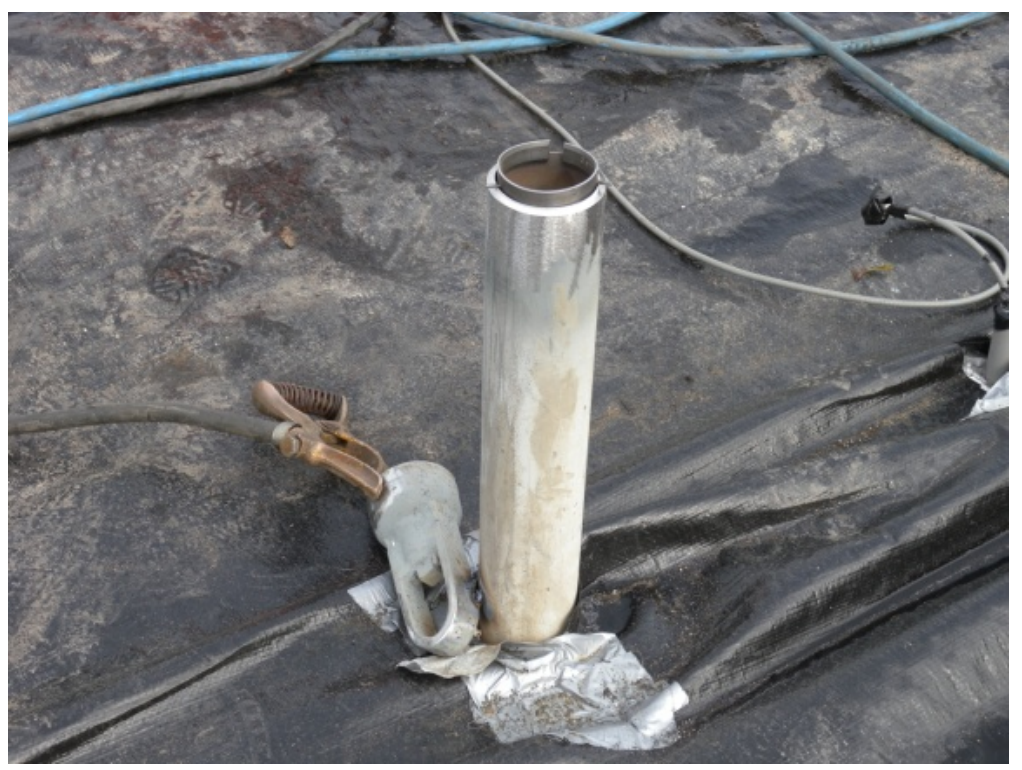

a. Top of evaporator.

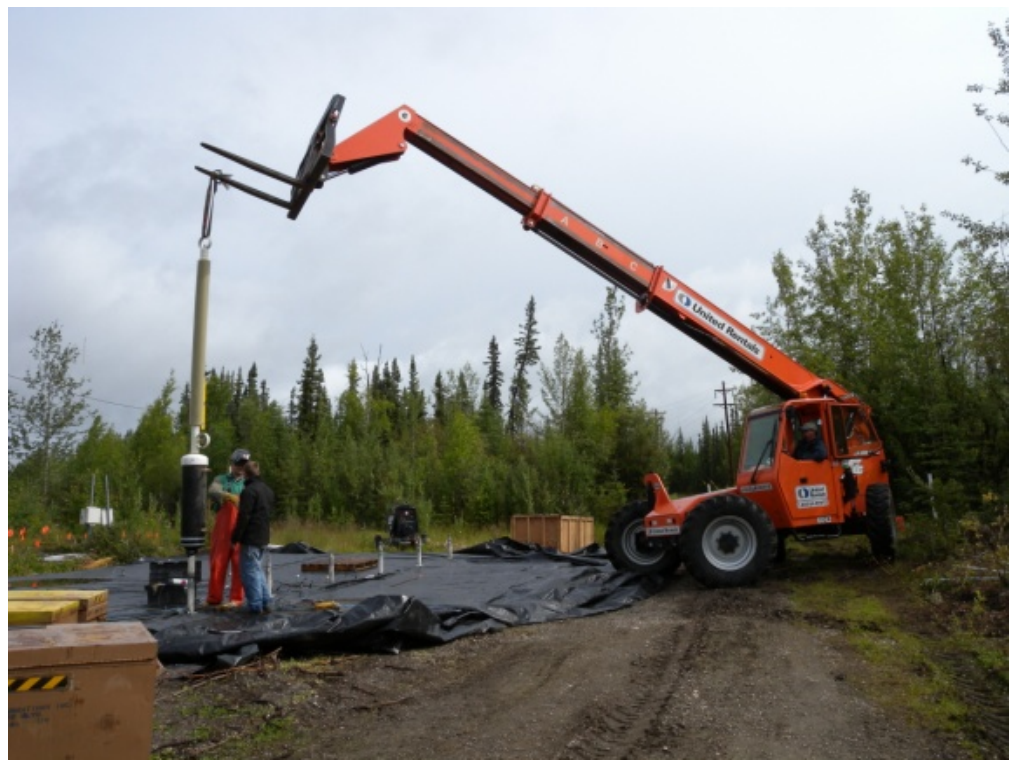

b. Placement of condenser.

Figure 8. Installation of condenser. 


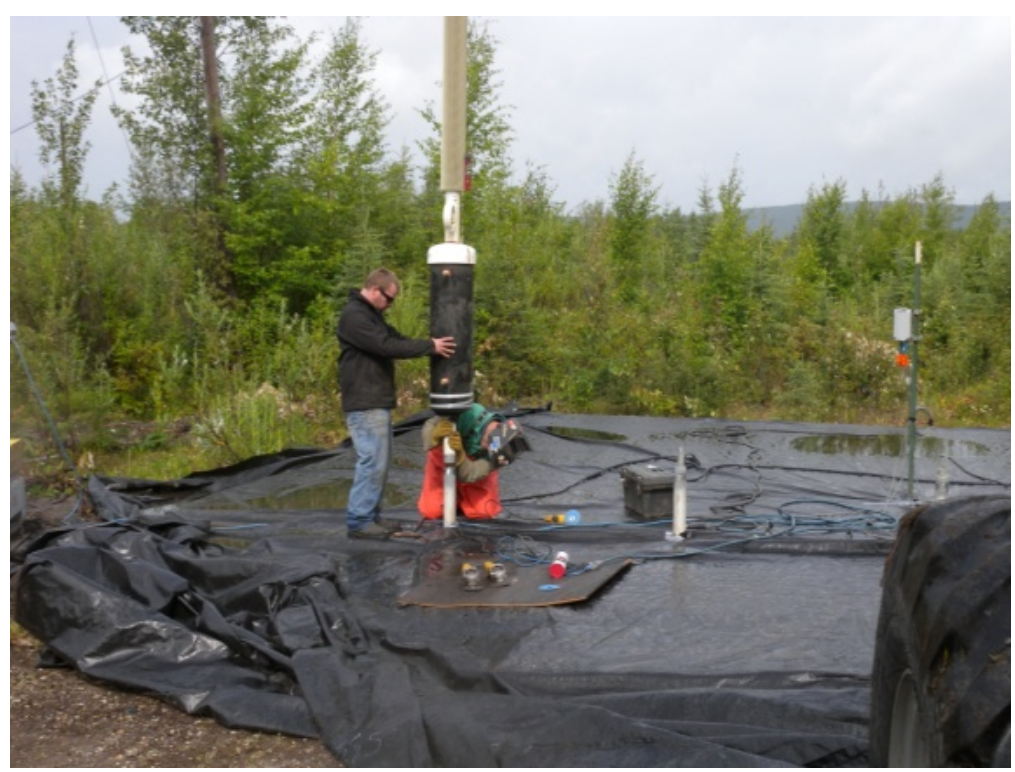

c. Aligning condenser on top of evaporator.

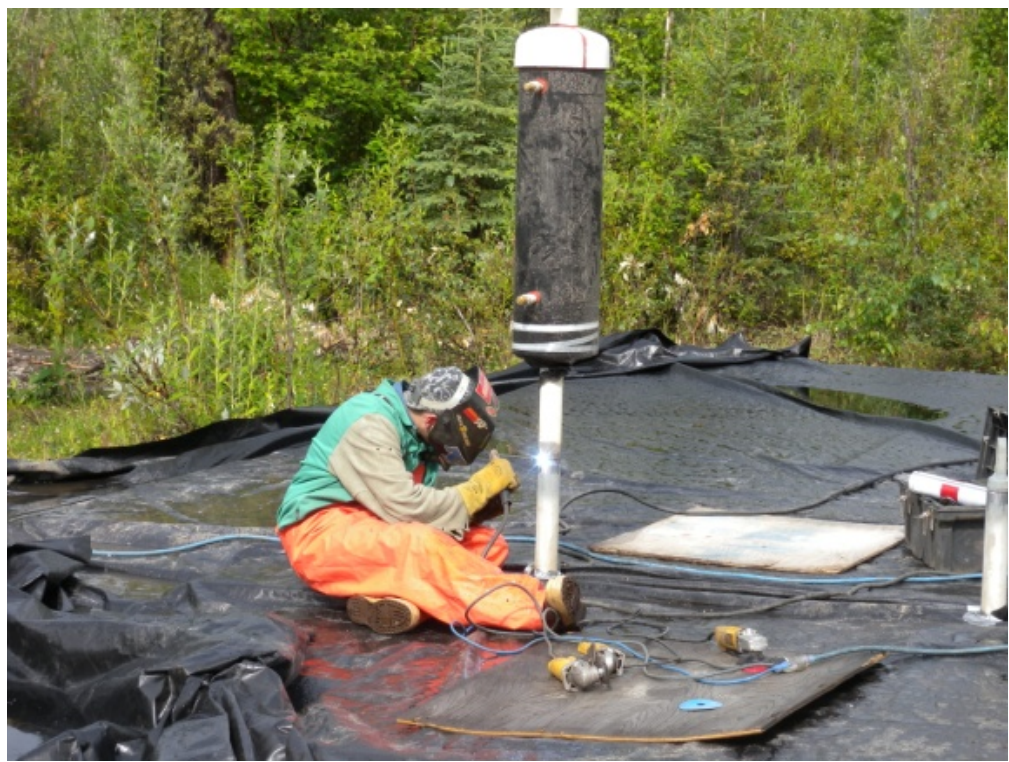

d. Joining of the evaporator and condenser.

Figure 8 (cont'd). Installation of condenser. 


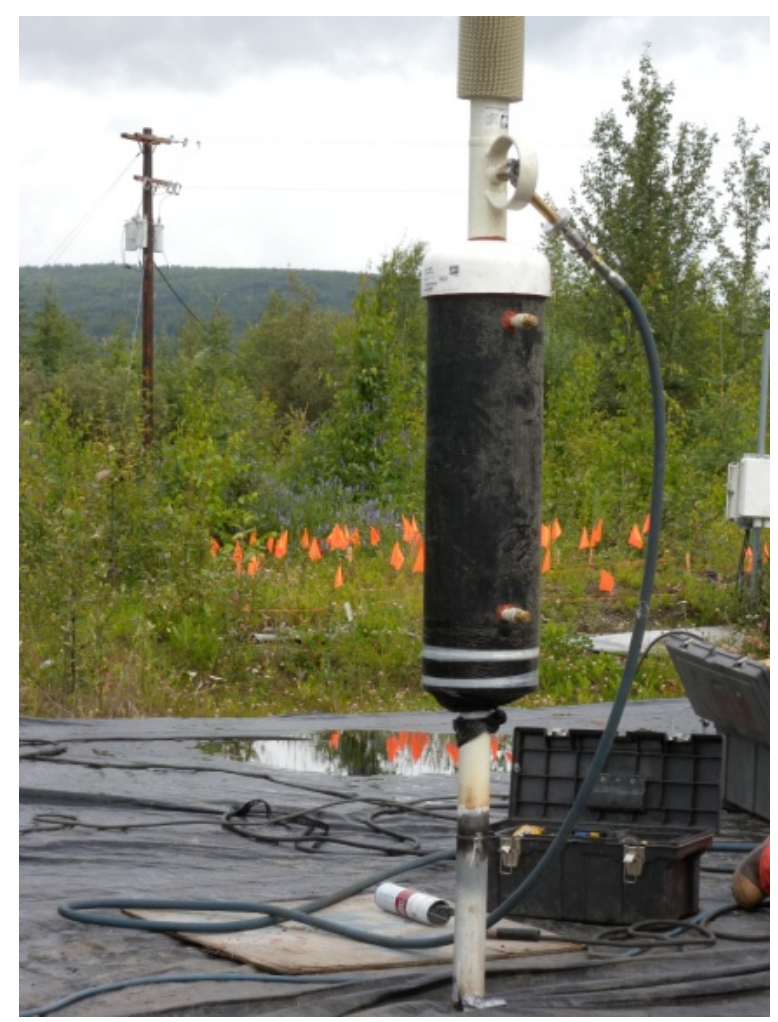

a. Purging.

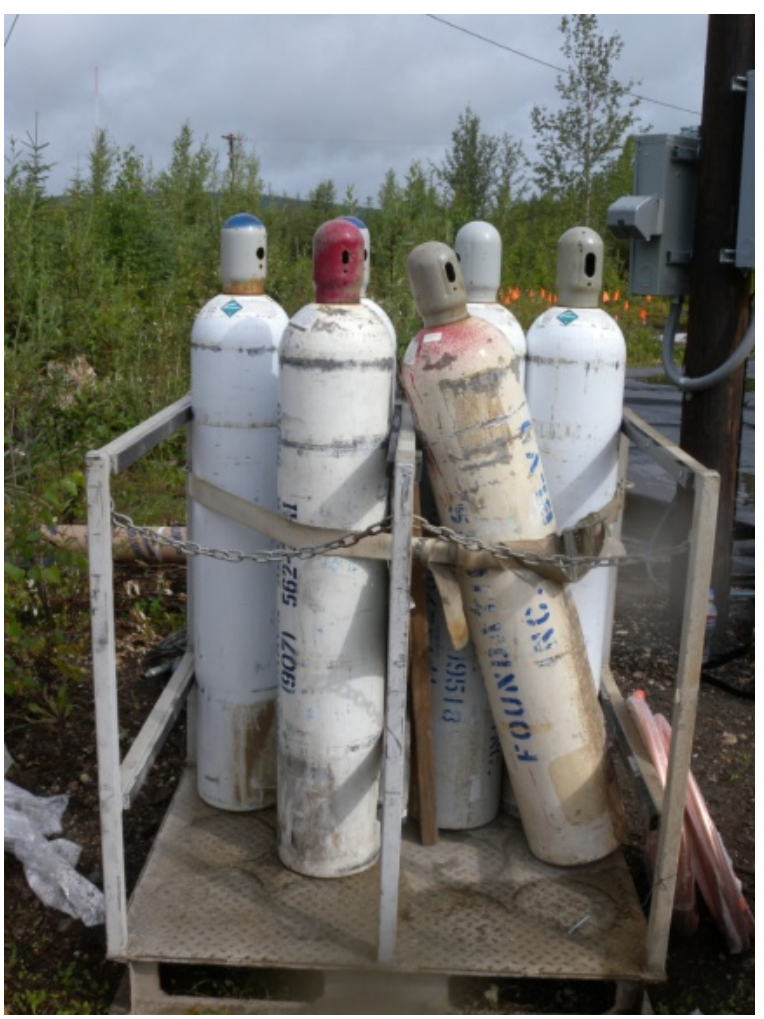

b. $\mathrm{CO}_{2}$ canisters.

Figure 9. Purging of the thermosyphon. 


\subsubsection{Refrigeration unit}

A 4.5-kW (6 hp) horizontal air discharge refrigeration unit manufactured by Bohn was used. The unit is $1.00 \mathrm{~m}$ high, $0.93 \mathrm{~m}$ deep, $1.31 \mathrm{~m}$ wide, weighs $355 \mathrm{~kg}$, and has a cooling capacity of $11.4 \times 10^{6} \mathrm{~kW}$ at a suction temperature of $-23.3^{\circ} \mathrm{C}$ and an ambient temperature of $35^{\circ} \mathrm{C}$. The unit was placed on top of the insulation and impermeable cover using a variable forklift (Fig. 10).

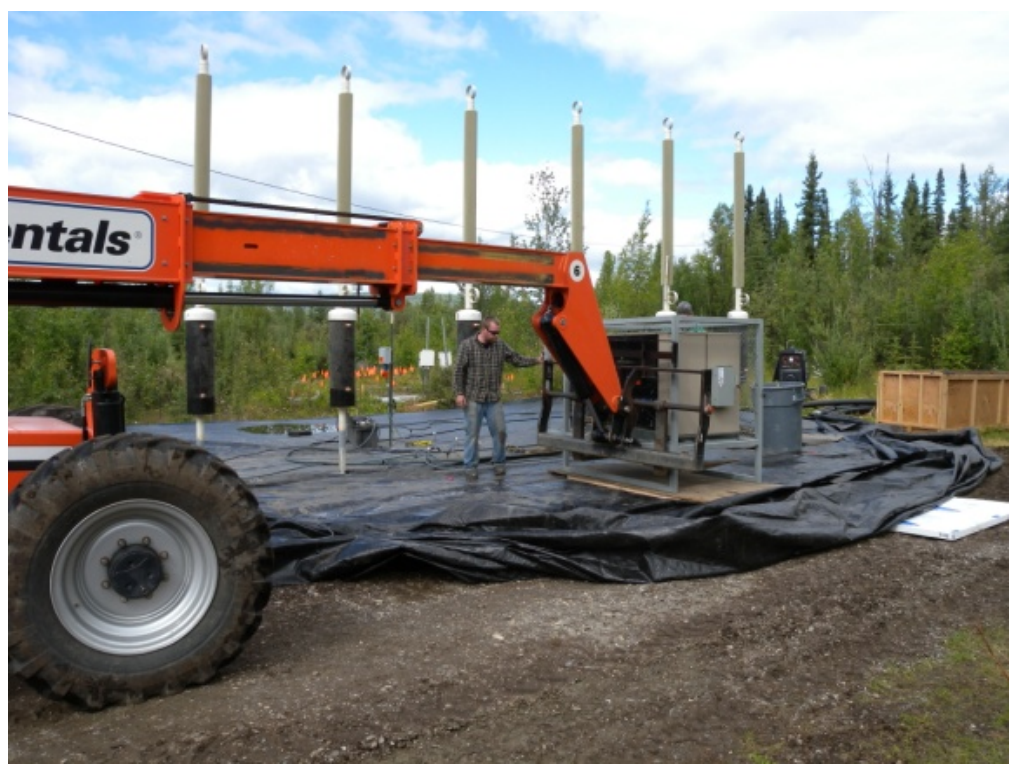

a. Refrigeration unit with fork lift.

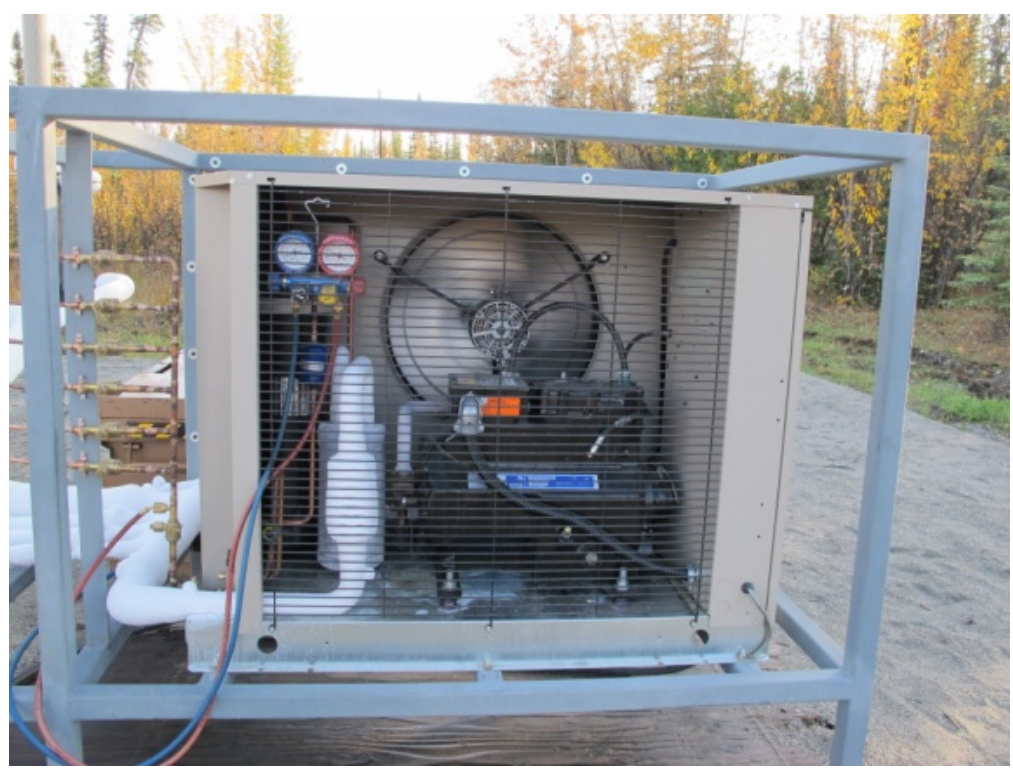

b. Close-up of refrigeration unit.

Figure 10. Placement of the refrigeration unit with a fork lift. 


\subsubsection{Insulation and impermeable cover}

The ground surface was insulated using $0.15 \mathrm{~m}$ of extruded polystyrene (Fig. 11) and a 0.3-mm membrane was placed on top (Fig. 12) to preclude surface water from infiltrating the insulated zone. In addition the blackcolored membrane was covered with sand to decrease heating of its surface by solar radiation (Fig. 13). This design was used to ensure the freeze barrier would extend from the permafrost up to the ground surface and to limit heat transfer to the upper portion of the barrier.

For colder locations, where contaminants are deeper than the seasonal thaw, insulation is not needed. Also, unless a high infiltration of rainfall is expected, the cover can be omitted in the design as well. At more temperate and warmer sites, the need for this type of protection depends on the depth of contaminants and expected rainfall infiltration. Furthermore, the insulation could be limited to only a strip wide enough to cover the thickness of the desired barrier (centered over the barrier).
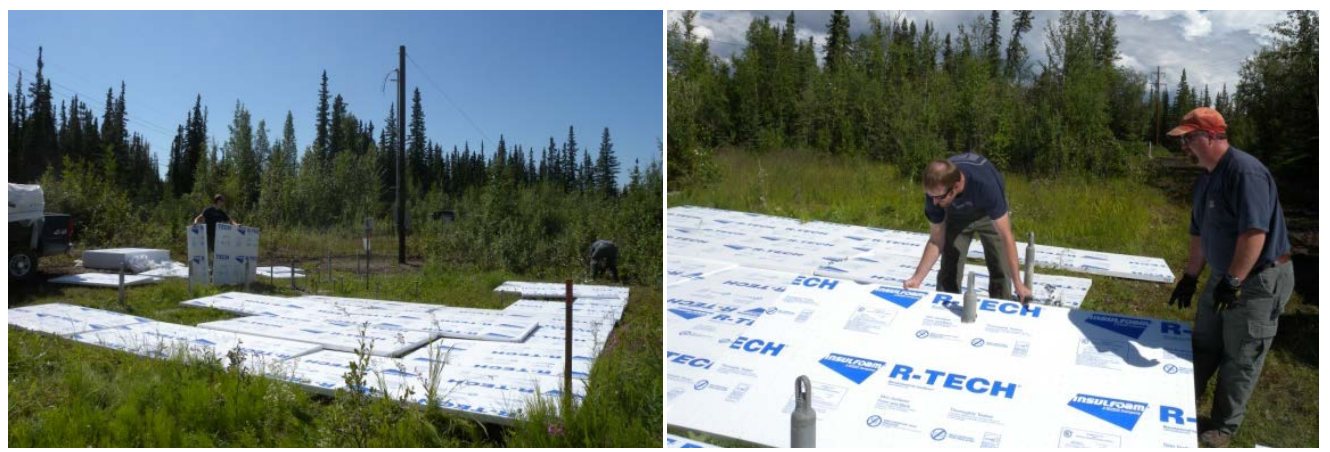

Figure 11. Installation of insulation.

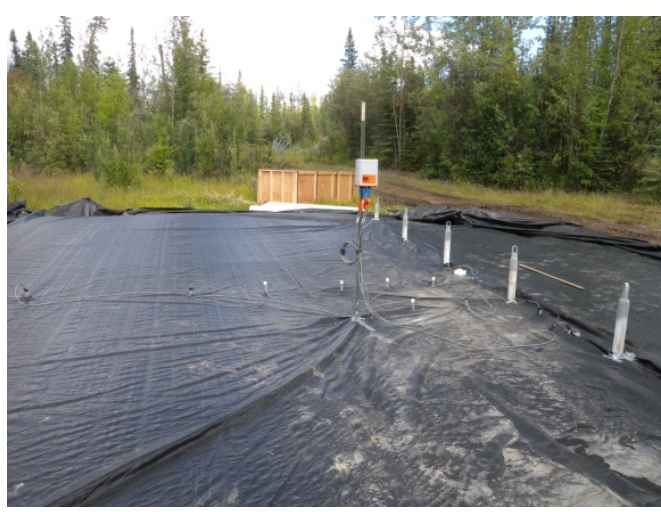

Figure 12. Impermeable cover. 


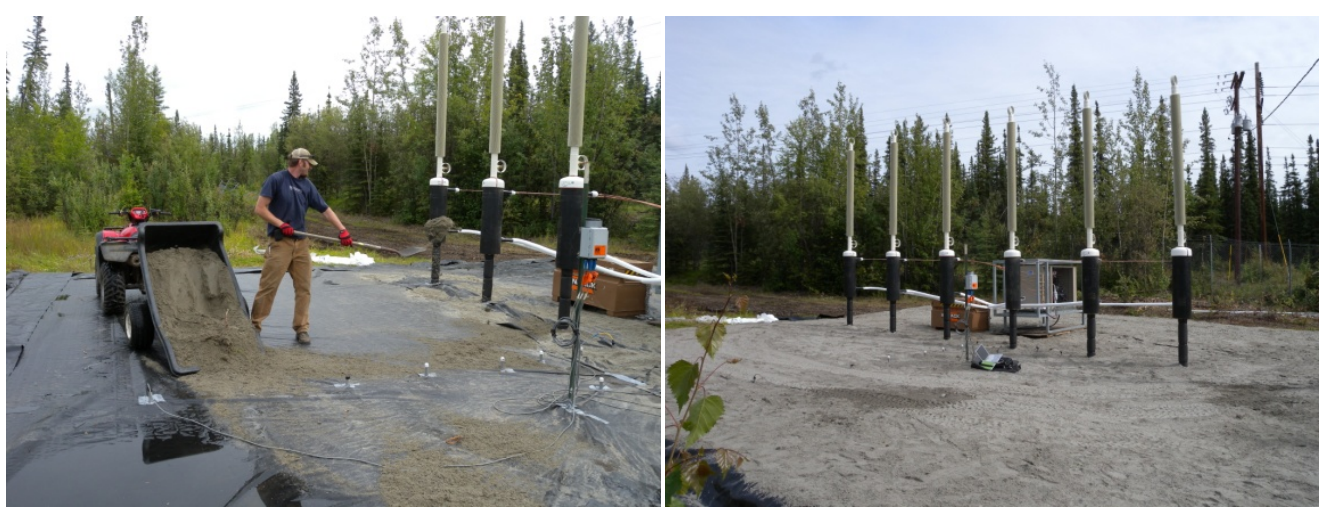

Figure 13. Sand cover.

\subsection{Ground temperature monitoring}

At this installation, thermistor strings were used to monitor the time to closure of the barrier. The freezing front is advancing (or retreating) through time, resulting in a need to monitor the ground temperature at different distances from the barrier in addition to at different depths. Therefore, thermistor tubes (or casings), Schedule 80 PVC pipes with a nominal diameter of $19.1 \mathrm{~mm}$, were installed for optimal use of the available thermistor strings. These tubes were installed in holes drilled using the GeoProbe (Fig. 14). The gaps between the native soil and the PVC pipes were backfilled with silica sand (Fig. 15). In addition to placing the tubes soil samples were collected using the Macro-Core $\mathrm{MC}^{5}$ soil sampler with a nominal diameter of $31.8 \mathrm{~mm}$ (Fig. 16).

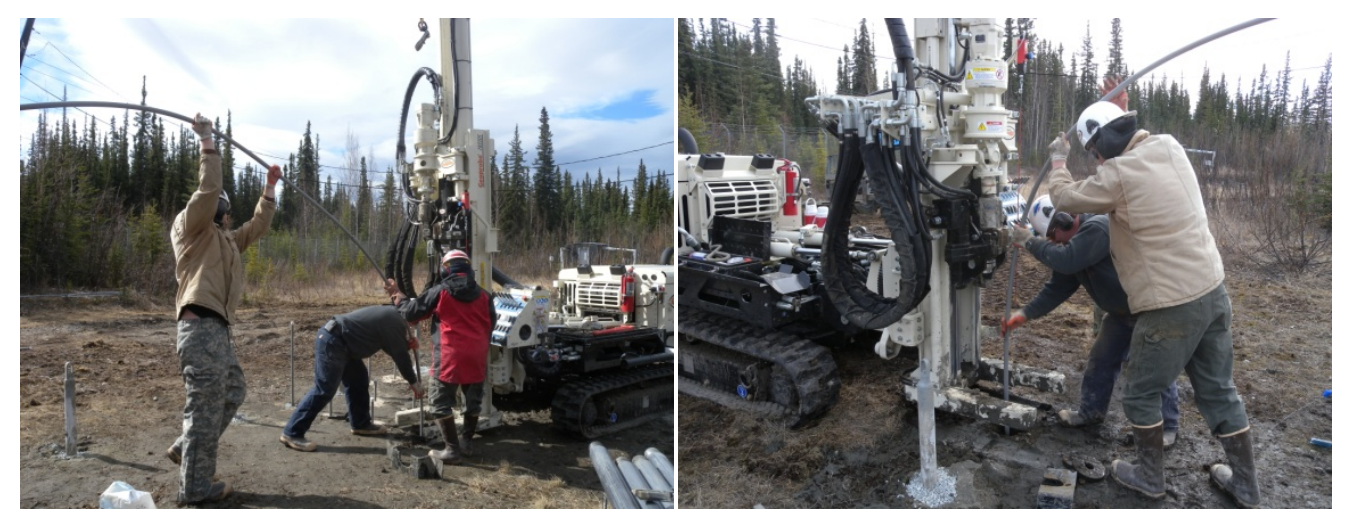

Figure 14. Placement of PVC pipes for ground temperature monitoring. 


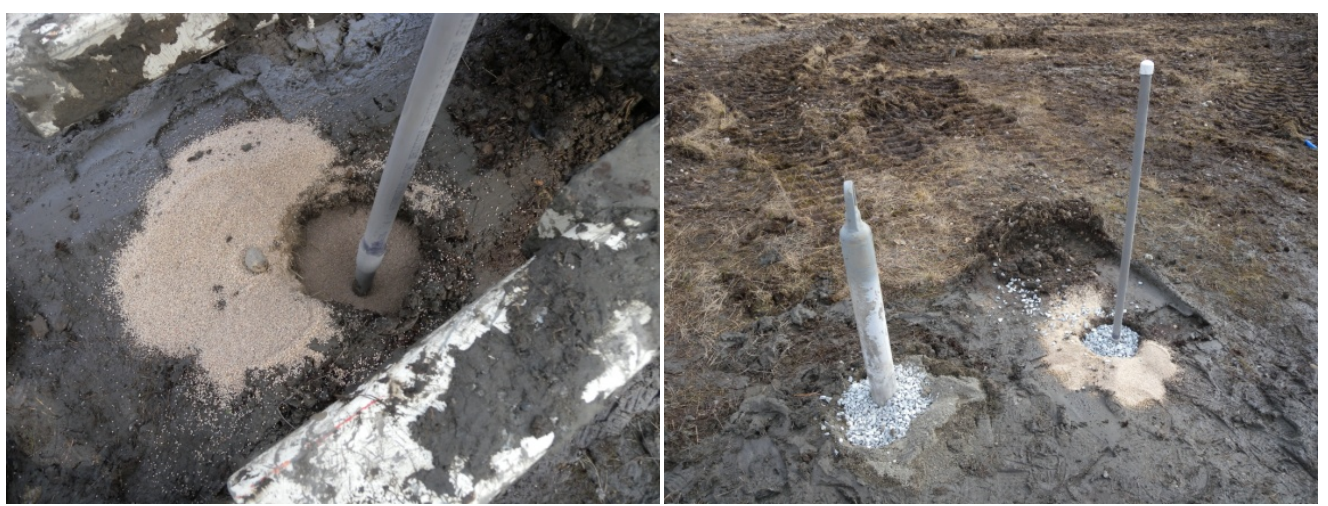

Figure 15. Sand backfill of ground temperature PVC pipe, and evaporator and temperature tube (ITTP50).

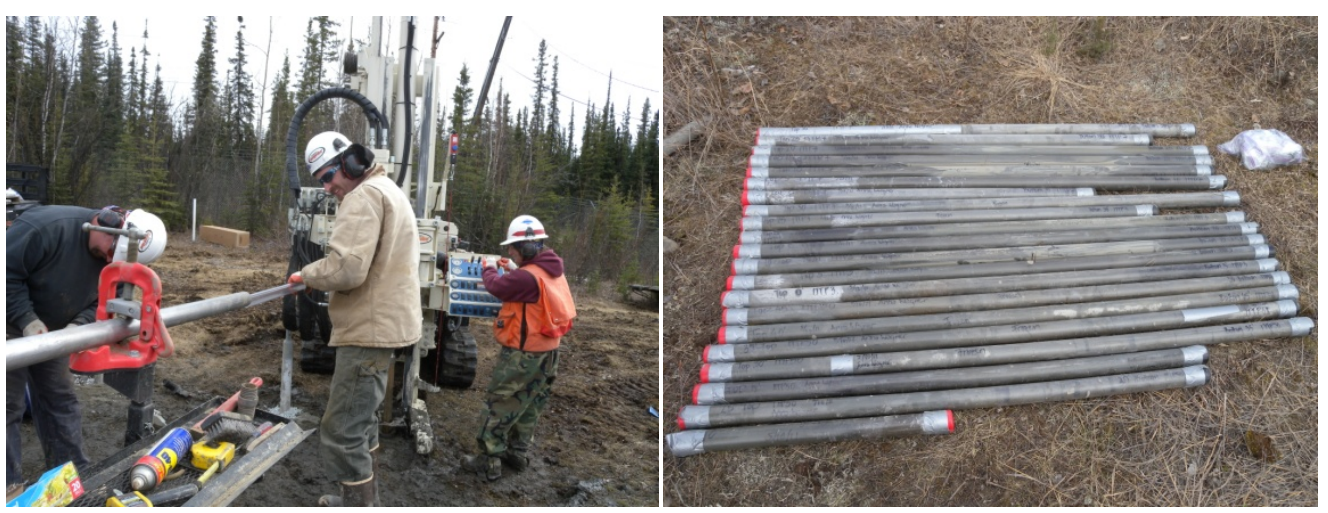

Figure 16. Collection of soil cores.

Six thermistor strings special-ordered from BeadedStream were used in addition to one DL330 data logger. One string was $15.2 \mathrm{~m}$ long with thermistors at $0,0.6,1.2,1.8,2.4,3.0,4.6,6.1,7.6,9.1,10.7,12.2,13.7$, and $15.2 \mathrm{~m}$ below the ground surface (where 0 is the insulation- ground interface). The other four strings were $10.7 \mathrm{~m}$ long and had thermistors placed at $0,0.6,1.2,1.8$, $2.4,3.0,4.6,6.1,7.6,9.1$, and $10.7 \mathrm{~m}$ below the ground surface. Three strings (placed in ITTP50, ITTP1, and ITTP10, see Fig. 17) recorded ground temperature continuously, whereas the other two were moved between different locations depending on the freezing front. ITTP10 was placed at a sufficient distance from the line of thermosyphons to not be affected by the freezing front. This string is referred to as the "control" string in the following text. Unfortunately, the ITTP50 hole was drilled just short of $15.2 \mathrm{~m}$ deep, resulting in the top sensor not being placed at the ground- insulation interface. To compare the top sensors with the other strings, we decided to adjust this string by placing the second sensor at the insulation- ground interface. This resulted in the sensors for this string recording temperatures at $0,0.6,1.2,1.8,2.4,3.9,5.5$, 7.0, 8.5, 10.1, 11.6, 13.1, and $14.6 \mathrm{~m}$ below the surface. 


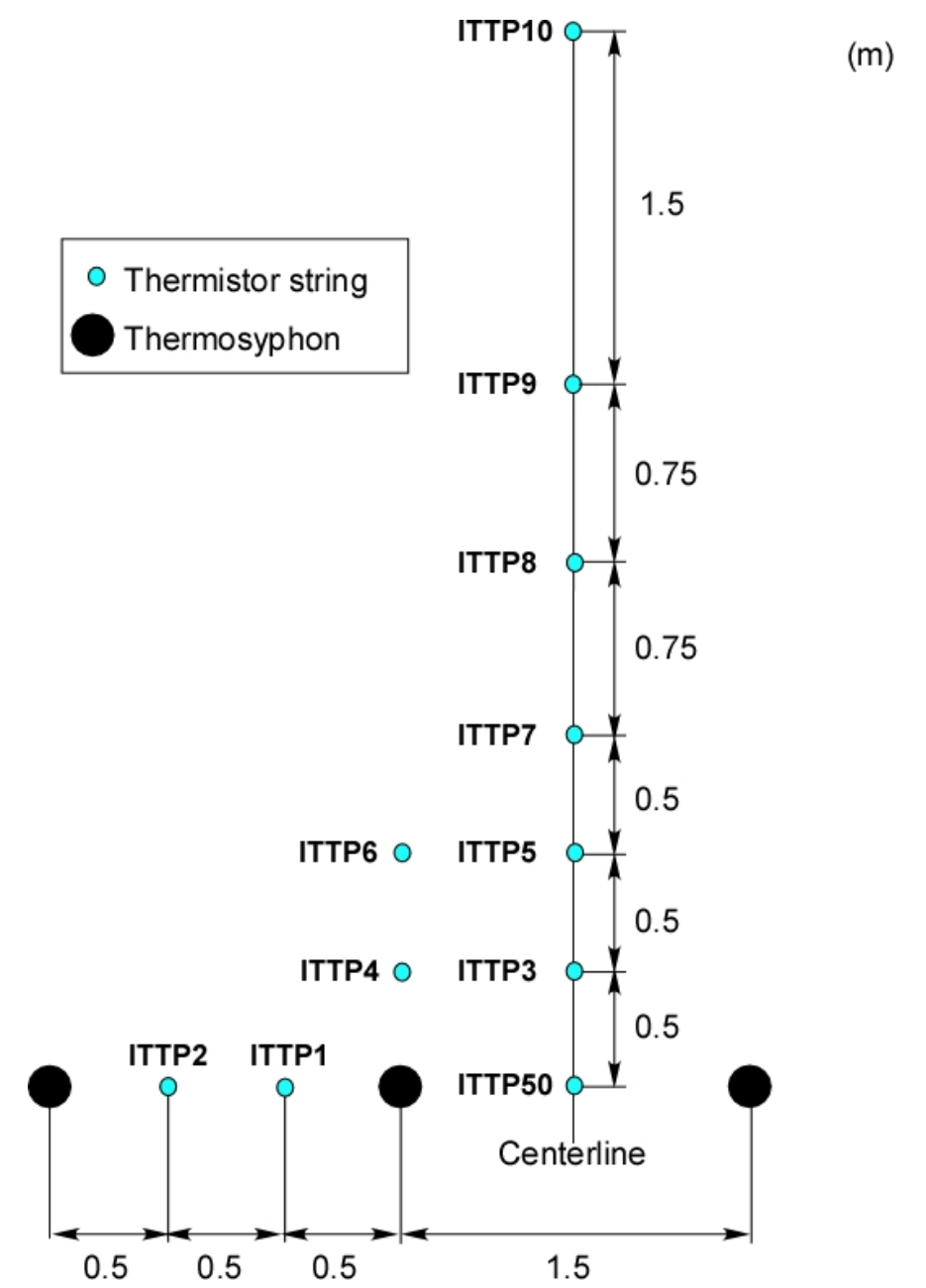

Figure 17. Layout of ground temperature monitoring locations. 


\section{Results and Discussion}

\subsection{Ground temperature measurements}

The ground temperatures were monitored throughout the active phase and the beginning of the passive phase, totaling 81 days. The active system started on 17J uly 2011 and the system went into its passive phase on 17 September 2011. The passive system was monitored for 19 days. At the start and end of the active system's function, the average air temperatures were 14 and $6^{\circ} \mathrm{C}$, respectively. The ground temperatures prior to freezing were approximately 16 and $13^{\circ} \mathrm{C}$ at the surface and at a depth of $0.6 \mathrm{~m}$, respectively (see Table 1). Figures 18-21 show measured ground temperatures, with the black dashed lines indicating the start of the passive system.

In general the soil temperature decreased at all measured locations, with the greatest temperature decrease at ITTP1 and ITTP2. These two strings are installed in-between two thermosyphons (see Fig. 17). The lowest temperatures were measured at these locations because they are installed the closest to the thermosyphons compared to the other strings. Once the active system is turned off, there is an increase in ground temperatures at all locations and depths (Fig. 18-21). Although the active system was turned off for 19 days, the ground remained frozen even at the interface between the ground surface and the insulation. For a system that would be designed to only run in an active phase, this could be looked upon as an electricity outage. The barrier would still be intact even if there was an extended electricity outage.

During the time of the active phase, the entire soil column froze up to the surface at ITTP1, ITTP2, ITTP3, ITTP4, and ITTP50, resulting in at least a barrier thickness of $1 \mathrm{~m}$. At the surface, the ground temperature decreased $20.6^{\circ} \mathrm{C}$ at ITTP50 compared to about $8.4^{\circ} \mathrm{C}$ at ITTP10 (the control). At ITTP10 the temperature decreased owing to the $0.15 \mathrm{~m}$ of insulation, but the decrease was not as rapid as at ITTP50. At a depth of $2.4 \mathrm{~m}$ there was a decrease in ground temperature of $12.9^{\circ} \mathrm{C}$ compared to an increase of $1.5^{\circ} \mathrm{C}$ at the control. The effective temperature decrease (difference between ITTP50 and control) at the ground surface was $12.2^{\circ} \mathrm{C}$. This temperature difference increased as depth increased. 

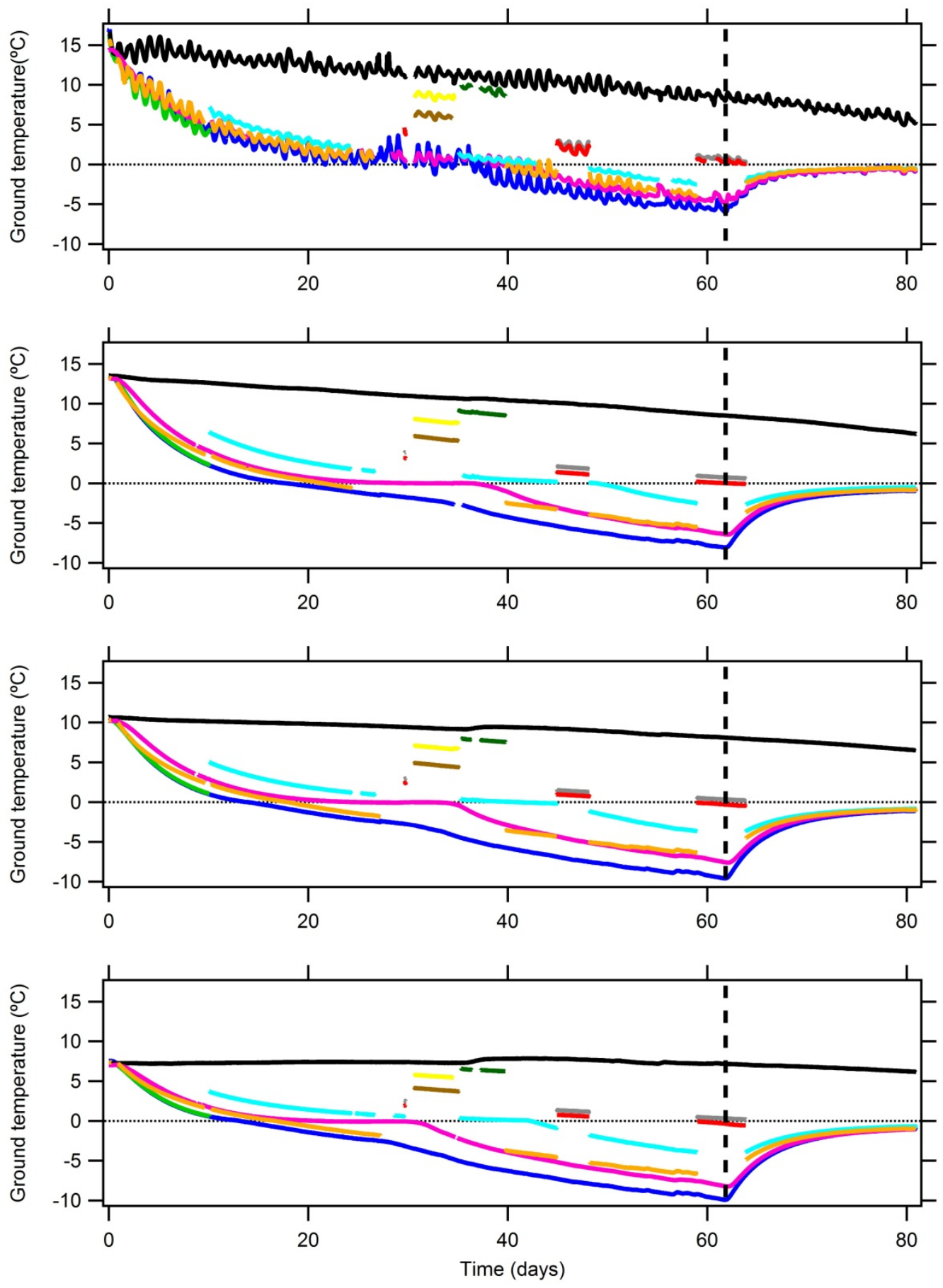

\begin{tabular}{|c|c|c|c|}
\hline $\begin{array}{l}- \text { ITTP1 } \\
\\
\text { ITTP7 }\end{array}$ & $\begin{array}{r}- \text { ITTP2 } \\
\text { ITTP8 }\end{array}$ & $\begin{array}{l}- \text { ITTP3 } \\
\text { ITTP9 }\end{array}$ & $\begin{array}{ll}\text { ITTP4 } & \text { ITTP5 } \\
\text { ITTP10 } & \text { ITTP50 }\end{array}$ \\
\hline
\end{tabular}

Figure 18. Ground temperatures for several locations (ITTP1, ITTP2, ITTP3, ITTP4, ITTP5, ITTP6, ITTP7, ITTP8, ITTP9, ITTP10, and ITTP50) at ground depths of surface (top, interface between ground surface and insulation), $0.6,1.2$, and $1.8 \mathrm{~m}$. The black dotted and dashed lines indicate the zero degrees freezing and start of the passive system respectively. 

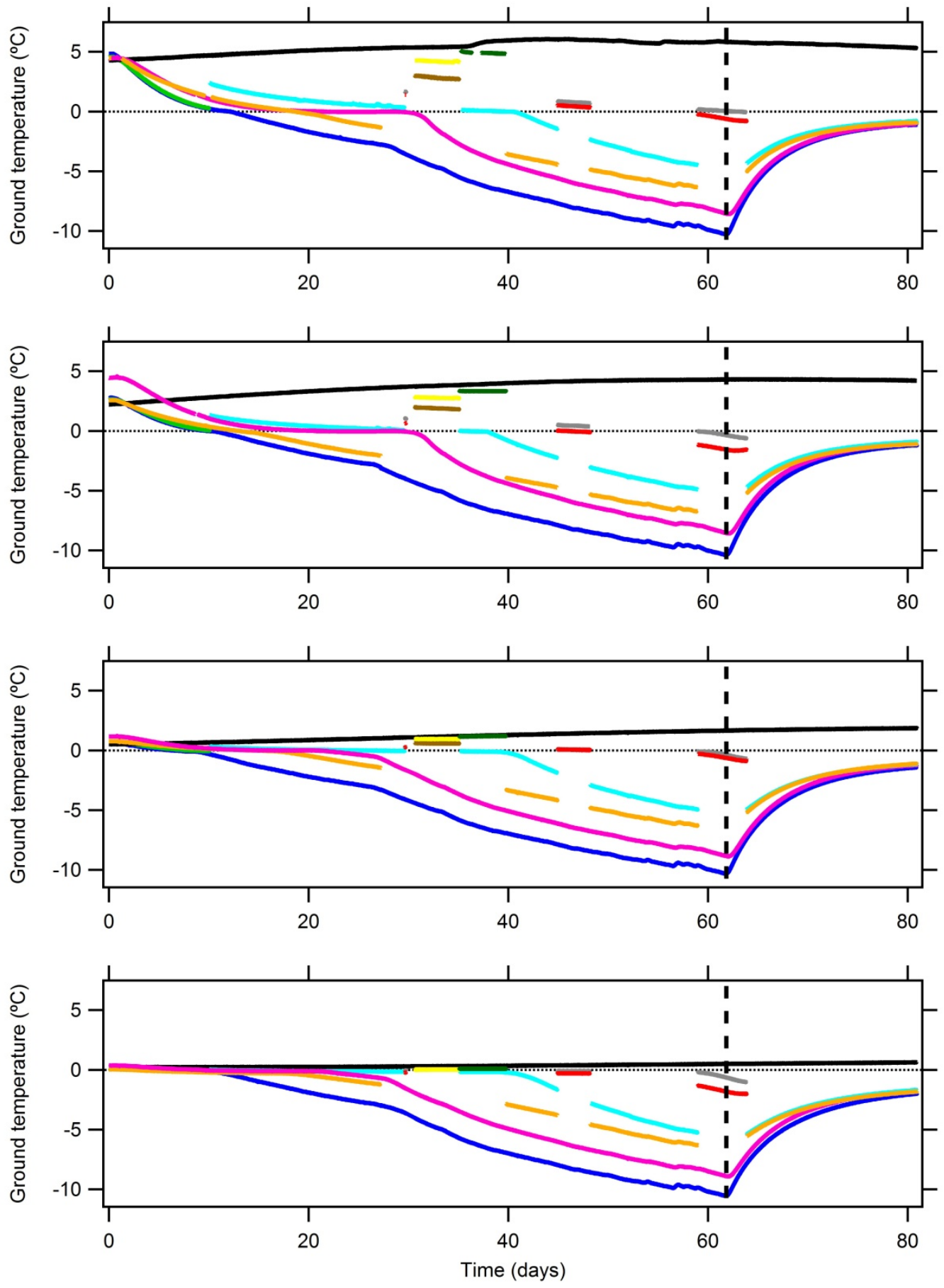

\begin{tabular}{|c|c|c|c|c|}
\hline $\begin{array}{ll}\text { ITTPP1 } \\
\text { ITTP7 }\end{array}$ & $\begin{array}{ll}\text { ITTP2 } \\
\text { ITTP8 }\end{array}$ & $\begin{array}{l}\text { ITTP3 } \\
\text { ITTP9 }\end{array}$ & $\begin{array}{ll}- & \text { ITTP4 } \\
& \text { ITTP10 }\end{array}$ & $\begin{array}{l}- \text { ITTP5 } \\
- \text { ITTP50 ITTP6 }\end{array}$ \\
\hline
\end{tabular}

Figure 19. Ground temperatures for several locations (ITTP1, ITTP2, ITTP3, ITTP4, ITTP5, ITTP6, ITTP7, ITTP8, ITTP9, ITTP10, and ITTP50) at ground depths of 2.4 (top), 3.0, 4.6, and $6.1 \mathrm{~m}$ (note that ITTP50 in second, third, and fourth graphs shows depths of 2.4, 4.0, and 5.5 $\mathrm{m}$, respectively). The black dotted and dashed lines indicate the $0^{\circ} \mathrm{C}$ freezing and start of the passive system respectively. 

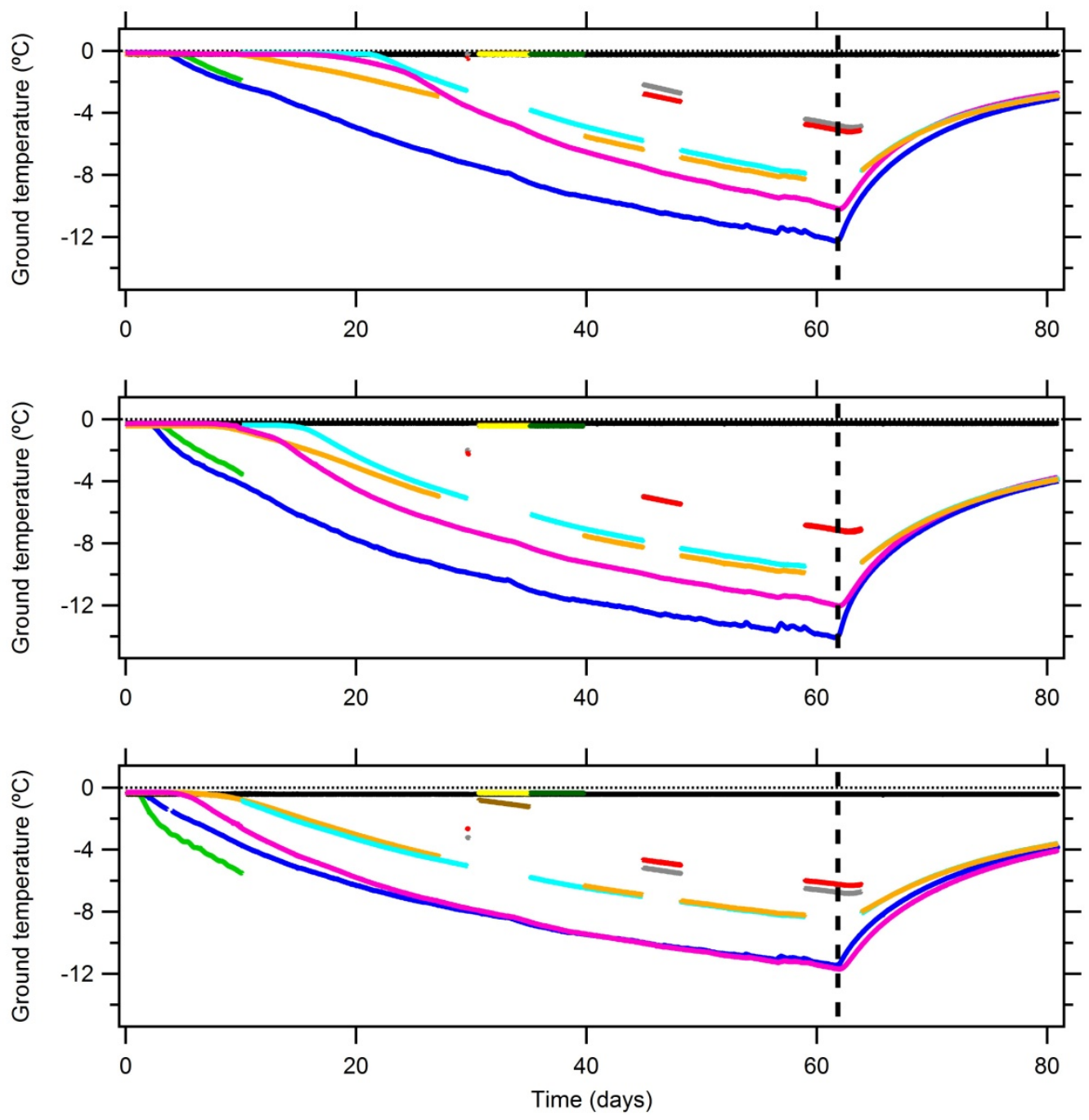

\begin{tabular}{|lrlll}
\hline ITTP1 & ITTP2 & ITTP3 & - ITTP4 & ITTP5 \\
ITTP7 & ITTP8 & - ITTP9 & - ITTP10 & ITTP6 \\
ITTP50
\end{tabular}

Figure 20 Ground temperatures for several locations (ITTP1, ITTP2, ITTP3, ITTP4, ITTP5, ITTP6, ITTP7, ITTP8, ITTP9, ITTP10, and ITTP50) at ground depths of surface, 7.6, 9.1, and $10.7 \mathrm{~m}$ (note that ITTP50 in all panels shows depths of 7.0, 8.5, and $10.0 \mathrm{~m}$ respectively). The black dotted and dashed lines indicate the $0^{\circ} \mathrm{C}$ freezing and start of the passive system respectively. 


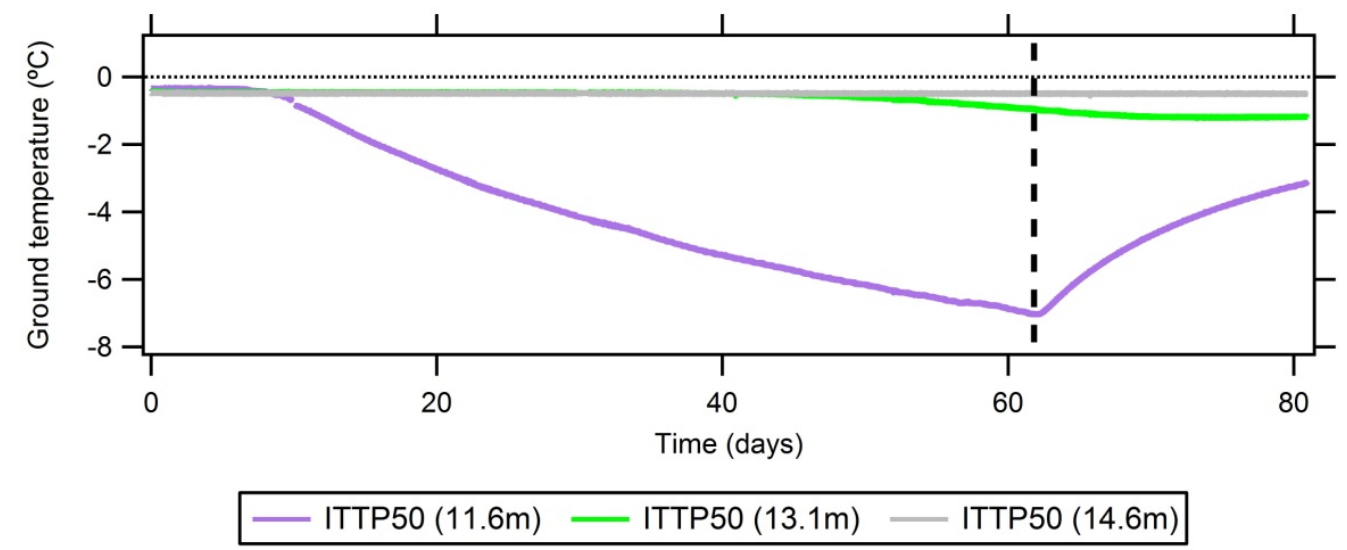

Figure 21. Ground temperatures for ITTP50 at depths of 11.6, 13.1, and $14.6 \mathrm{~m}$. The black dotted and dashed lines indicate the zero degrees freezing and start of the passive system respectively.

Table 1. Active system start and end temperatures for ITTP10 (control) and ITTP50 (middle of barrier) at different ground depths $(0,0.6,1.2,1.8$, and $2.4 \mathrm{~m})$. The effective temperature difference is the difference between the decrease in ground temperature for ITTP50 and ITTP10.

\begin{tabular}{|l|r|r|r|r|r|r|r|r|r|c|}
\hline & \multicolumn{9}{|c|}{ ITP50 (middle of barrier) $\left({ }^{\circ} \mathrm{C}\right.$ ) } & \multicolumn{5}{|c|}{ ITTP10 (control) $\left({ }^{\circ} \mathrm{C}\right)$} \\
\hline Depth $(\mathrm{m})$ & 0 & 0.6 & 1.2 & 1.8 & 2.4 & 0 & 0.6 & 1.2 & 1.8 & 2.4 \\
\hline Start active & 15.7 & 13.3 & 10.3 & 7.3 & 4.4 & 16.4 & 13.6 & 10.7 & 7.3 & 4.3 \\
\hline End active & -4.9 & -6.4 & -7.6 & -8.2 & -8.5 & 8.0 & 8.5 & 8.1 & 7.2 & 5.8 \\
\hline $\begin{array}{l}\text { Temperature } \\
\text { difference (end- } \\
\text { start) }\end{array}$ & -20.6 & -19.7 & -17.9 & -15.5 & -12.9 & -8.4 & -5.1 & -2.6 & -0.1 & 1.5 \\
$\begin{array}{l}\text { Effective } \\
\text { temperature } \\
\text { difference }\end{array}$ & -12.2 & -14.6 & -15.3 & -15.4 & -14.4 & & & & & \\
\hline
\end{tabular}




\subsection{Electricity usage}

The active system runs on power and its power use is proportional to the air temperatures. Figure 22 shows the electricity usage during the active phase in addition to the air temperature. It can be seen that the power use decreases with a decreasing air temperature. In Fairbanks, AK, the electricity costs $\$ 0.20 / \mathrm{kWh}$, resulting in an average cost per day ranging between $\$ 24$ and $\$ 29$ during the active phase.

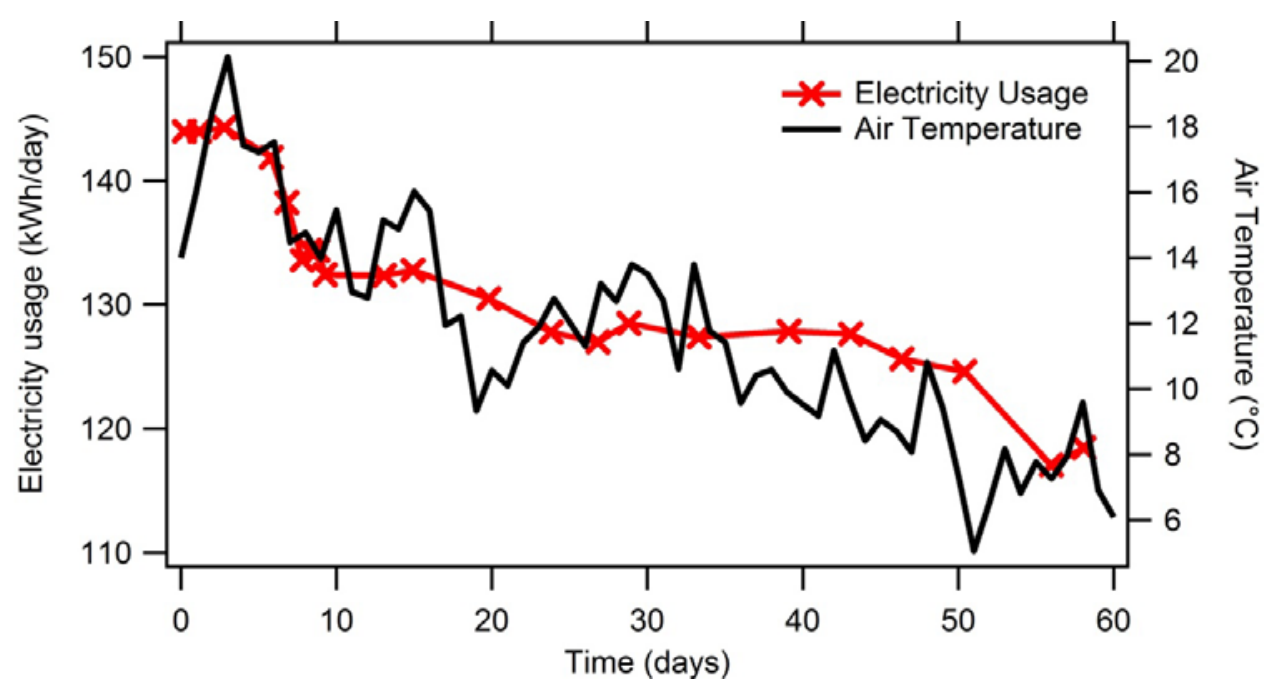

Figure 22. Electricity usage and average air temperatures during the active phase.

\subsection{Advantages of artificial frozen barriers}

There are several advantages to using frozen barriers to contain contaminants. Frozen barriers can readily be deployed at most any site provided that the freezing tubes can be installed. The barrier can be established whether the materials adjacent are soil, rock, or other solids. These materials usually cause problems when more traditional techniques, such as grouting, are used (Hass and Schäfers 2006). If the material's temperature can be lowered to below freezing, then it can be incorporated into the barrier. For example, a frozen barrier can be implemented where numerous pipes and wires transect the barrier without having to remove the pipes and wires. Details of the materials should be known so that the barrier is not breached because of pathways created by the material.

Frozen barriers are self-healing if ruptured by an earthquake or blast-type event (Long and Yarmak 2000). Moisture will flow into the cracks in a 
barrier and freeze the broken parts together. Typical barriers are on the order of $3.7 \mathrm{~m}$ thick and it would take a severe ground displacement to cause a breach in a frozen barrier.

Barriers can be removed once the remediation is completed (Andersland et al. 1996). Essentially, the containment process is transient, i.e., thawing takes place once the source of chilling is removed. This allows conditions to return to "normal" without continued interference to the site hydrology, and thereby makes the technique environmentally friendly. Additionally, a frozen barrier can be installed at almost any depth-hundreds of metersand in nearly any configuration. The system is also versatile in that it can be used in any geologic formation or soil type that contains sufficient pore moisture. 


\section{References}

ADEC. 1996. Sufficiently impermeable secondary containment systems, Alaska Department of Environmental Conservation Division of Spill Prevention and Response Industry Preparedness and Pipeline Program. March 11.

Andersland, O. B., D. C. Wiggert, et al. 1996. Hydraulic conductivity of frozen granular soils. J ournal of Environmental Engineering 122(3): 212- 216.

ASHRAE. 1998. 1998 Refrigeration handbook: 35.3- 35.5. Atlanta, Georgia: American Society of Heating, Refrigerating and Air-Conditioning Engineers, Inc.

French, H. M. 2007. The periglacial environment. Chichester: J . Wiley.

Hass, H., and P. Schäfers. 2006. Application of ground freezing for underground construction in soft ground. Geotechnical Aspects of Underground Construction in Soft Ground. London: Taylor \& Francis.

Long, E. L. 1963. The Long thermopile. In Permafrost: Proceedings of an international conference, National Academy of Sciences, Washington D.C.

Long, E. L., and E. Yarmak, J r. 2000. Engineering and economic variables of long duration frozen barriers. In International Symposium on Ground Freezing and Frost Action in Soils. Louvain-la-Neuve, Belgium.

Lynn, S. W., S. Rock, et al. 2000. Evaluation of a vertical frozen soil barrier at oak ridge national laboratory. Remediation J ournal 10(3): 15- 33.

McCauley, C. A., D. M. White, et al. 2002. A comparison of hydraulic conductivities, permeabilities and infiltration rates in frozen and unfrozen soils. Cold Regions Science and Technology 34(2): 117- 125.

Sullivan, J ., J . D. Lynch, et al. 1984. The Economics of Ground Freezing for Management of Uncontrolled Hazardous Waste Sites. Municipal Environmental Research Laboratory, Office of Research and Development, U.S. Environmental Protection Agency.

USGAO. 2005. Groundwater Contamination DOD Uses and Develops a Range of Remediation Technologies to Clean up Military Sites. U.S. Government Accountability Offices. GAO-05-666: 41.

USGS. 1993. What is Ground Water? U.S. Geological Survey. 93-643: 2. 


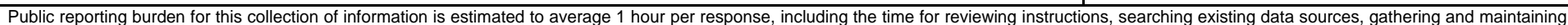

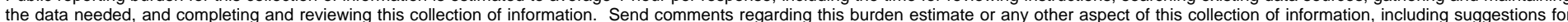

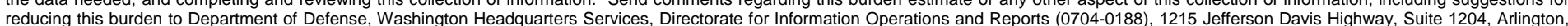

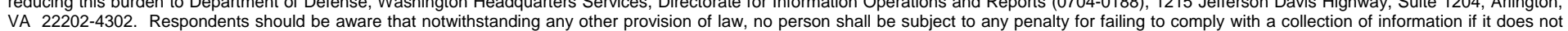
display a currently valid OMB control number. PLEASE DO NOT RETURN YOUR FORM TO THE ABOVE ADDRESS.
1. REPORT DATE $(D D-M M-Y Y Y Y)$ 2. REPORT TYPE
November 2012 Final
3. DATES COVERED (From - To)

4. TITLE AND SUBTITLE

Demonstration of an Artificial Frozen Barrier

5a. CONTRACT NUMBER

5b. GRANT NUMBER

5c. PROGRAM ELEMENT NUMBER

\section{AUTHOR(S)}

5d. PROJECT NUMBER

Anna M. Wagner and Edward Yarmak, Jr.

5e. TASK NUMBER

5f. WORK UNIT NUMBER

7. PERFORMING ORGANIZATION NAME(S) AND ADDRESS(ES)

8. PERFORMING ORGANIZATION REPORT NUMBER

Cold regions Research and Engineering Laboratory

U.S. Army Engineer Research and Development Center

ERDC/CRREL TR-12-12

72 Lyme Road

Hanover, NH 03755

9. SPONSORING I MONITORING AGENCY NAME(S) AND ADDRESS(ES)

U.S. Army Corps of Engineers

Washington, DC 20314-1000

10. SPONSOR/MONITOR'S ACRONYM(S)

11. SPONSOR/MONITOR'S REPORT NUMBER(S)

\section{DISTRIBUTION / AVAILABILITY STATEMENT}

Approved for public release; distribution is unlimited.

\section{SUPPLEMENTARY NOTES}

\section{ABSTRACT}

Groundwater is the main source of drinking water for the majority of the U.S. population. Unfortunately, groundwater is susceptible to contamination from major sources, such as storage tanks, hazardous waste sites, landfills, and septic systems. Polluted groundwater can endanger public health or threaten the environment. Standard containment technologies include slurry walls, reactive barriers, sheet piling, and grouting. Another less common technique is freezing the contaminants in situ. The objective of this study is to create a frozen soil barrier using thermosyphons. The first phase of this study is presented in this report and investigated how long it takes for the rate of bulk soil freezing to complete the frozen soil barrier. At this installation, freezing to closure occurred after about 42 days and the barrier was $1 \mathrm{~m}$ thick after approximately 48 days. The average electricity usage was $132 \mathrm{kWh} / \mathrm{day}$.

\begin{tabular}{ll}
\hline 15. SUBJECT TERMS & Frozen barrier \\
Containment & Groundwater \\
Contaminants & Pollution contro
\end{tabular}

16. SECURITY CLASSIFICATION OF:

a. REPORT

U

b. ABSTRACT

U

c. THIS PAGE

U

Thermosyphons

18. NUMBER OF PAGES

17. LIMITATION OF ABSTRACT

None
37 19a. NAME OF RESPONSIBLE PERSON

19b. TELEPHONE NUMBER (include area code) 